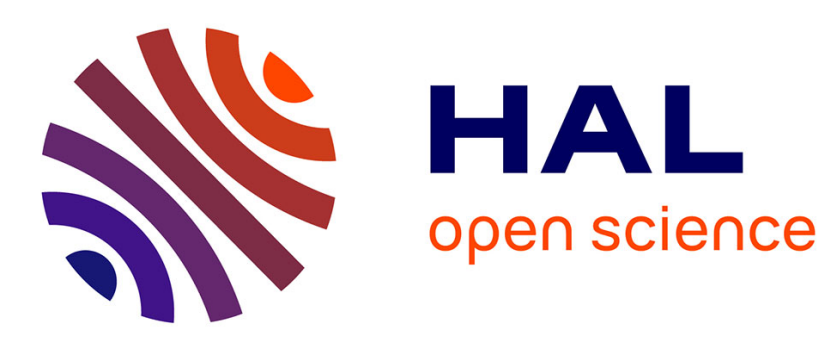

\title{
On Śaiva Terminology: Some Key Issues of Understanding
}

Lyne Bansat-Boudon

\section{To cite this version:}

Lyne Bansat-Boudon. On Śaiva Terminology: Some Key Issues of Understanding. Journal of Indian Philosophy, 2014. hal-01448280

\section{HAL Id: hal-01448280 \\ https://hal.science/hal-01448280}

Submitted on 27 Jan 2017

HAL is a multi-disciplinary open access archive for the deposit and dissemination of scientific research documents, whether they are published or not. The documents may come from teaching and research institutions in France or abroad, or from public or private research centers.
L'archive ouverte pluridisciplinaire HAL, est destinée au dépôt et à la diffusion de documents scientifiques de niveau recherche, publiés ou non, émanant des établissements d'enseignement et de recherche français ou étrangers, des laboratoires publics ou privés. 


\section{On Śaiva Terminology: Some Key Issues of Understanding}

\section{Lyne Bansat-Boudon}

\section{Journal of Indian Philosophy}

ISSN 0022-1791

Volume 42

Number 1

J Indian Philos (2014) 42:39-97

DOI 10.1007/s10781-013-9211-6

\section{Journal of Indian Philosophy}

\section{黛 Springer}


Your article is protected by copyright and all rights are held exclusively by Springer Science +Business Media Dordrecht. This e-offprint is for personal use only and shall not be selfarchived in electronic repositories. If you wish to self-archive your article, please use the accepted manuscript version for posting on your own website. You may further deposit the accepted manuscript version in any repository, provided it is only made publicly available 12 months after official publication or later and provided acknowledgement is given to the original source of publication and a link is inserted to the published article on Springer's website. The link must be accompanied by the following text: "The final publication is available at link.springer.com". 


\title{
On Śaiva Terminology: Some Key Issues of Understanding
}

\author{
Lyne Bansat-Boudon
}

Published online: 31 January 2014

(C) Springer Science+Business Media Dordrecht 2014

\begin{abstract}
The goal of this paper is to reconsider some key concepts of nondualist Kashmirian Śaivism whose interpretation and translation have generally been the subject of some sort of silent consensus. Through the close examination of a particular text, the Paramārthasāra of Abhinavagupta and its commentary by Yogarāja, as well as of related texts of the system, I shall attempt to improve upon the understanding and translation of terms such as ghana (and the compounds derived therefrom), the roots sphar, sphur, pra]kāś etc., and their derivatives, bhavanakartrtā, and the names of the three malas. Further, bhāvana will be discussed in its Śaiva acceptation and a more suitable translation suggested.
\end{abstract}

Keywords Śaivism - Śaiva terminology - Kashmirian Śaiva philosophy · Nondualism · Trika $\cdot$ Abhinavagupta

\footnotetext{
This paper was first presented at the special panel on 'Śaiva Philosophy' that Judit Törzsök and I organized for the 15th World Sanskrit Conference, held in Delhi in January 2012. It offers a developed version of various observations scattered in the notes and appendices to my translation of Abhinavagupta's Paramārthasāra (see n. 2). I would like to express my gratitude to Edwin Gerow, whose suggestions on the first section of this paper greatly improved its readability. I am also grateful to Judit Törzsök for her reading of a first draft of this essay and her insightful contribution on the points that were raised in our discussions.

L. Bansat-Boudon $(\bowtie)$

Ecole pratique des hautes études, section des sciences religieuses, Directeur d'études pour les « Religions de l'Inde: Etudes śivaïtes », Sorbonne University, Paris. Administration: 4-14 rue Ferrus, 75014 Paris, France

e-mail: Lyne.Bansat-Boudon@ephe.sorbonne.fr

L. Bansat-Boudon

53, rue Manin, 75019 Paris, France
} 
This paper will deal with Śaiva terminology, chiefly that of the nondualist Pratyabhijñā during what is traditionally called the 'age of the Exegetes', ${ }^{1}$ and will propose what I believe are more accurate translations for some of its key notions-notions whose interpretation and translation have generally been the subjects of a silent consensus.

Through the close examination of a particular text, the Paramārthasāra [PS] of Abhinavagupta, and its commentary by Yogarāja, the Paramārthasāravivirti [PSV], ${ }^{2}$ but often expanded by reference to related texts of the system, I shall attempt to improve upon the understanding and translation of terms such as ghana (and the compounds derived therefrom), the roots sphar, sphur, [pra]kāś etc., and their derivatives, bhavanakartrttā, and the names of the three malas. Further, bhāvanā will be discussed in its Śaiva acceptation and a more suitable translation suggested.

My main hope is to render more precisely the philosophical sense or purpose of some of these terms by according greater weight, when appropriate, to contextual intelligibility than to a presumed literalness based on etymology (which, needless to say, must still be the first stage of a translation exercise) - even though such translation would incur the cost of abandoning an original metaphor (as is the case with my propositions for the roots conveying the sememe of light).

In any case, I hope to avoid, as much as possible, the double temptation of a periphrasis that appropriates elements of the term's Sanskrit gloss (see infra, p. 49, some translations of sphurana, etc.) or the kind of hybrid morphology that consists in suffixing a Sanskrit stem with an element taken from the target language, which may be considered an easy way out, apart from the inevitable usage of such hybrids in designating philosophical and religious systems (Hindu-ism, Shaiv-ism, etc.).

A final desideratum would be the selection of a term or an expression that is recognized as natural in the target language and is fitted to its syntactical context.

One might suspect that the principle of avoiding periphrasis is far from being observed in the terms I propose for the three malas, for instance. ${ }^{3}$ My answer is that, although my translations for the three malas may appear to be expanded, the expansion is not a periphrasis but rather a syntactical suppletion - a suppletion made necessary not only by the transposition from Sanskrit to a language, such as English, which lacks the austere compositional facility of Sanskrit, but also by the philosophical discourse to be read through the terminology, where it is desirable to give preference to the subjective point of view of the bound soul (paśu) engaged in the process of achieving its ultimate freedom, sovereignty and purity (see, infra, p. 76).

\footnotetext{
1 In his works, Abhinavagupta designates the doctrine of which he is a notable exponent (indeed, the most fecund), namely nondualistic Śaivism, as the 'Trika', or 'Triad'. Therefore, in what follows, I shall also refer to this system of thought with this term. On the Trika, or 'Triad' of three principles: Śiva, Śakti and the embodied soul (nara), see, for instance, Tantrāloka [TĀ] X 1, XIII 348 and (as the periphrastic expression 'sadardha', 'half of six') TĀ XIII 301 (where is established the supremacy of the Trika over all Śaiva currents), XVI 158, XXXVII 26, 68, etc. On the historical development of the Trika and other symbolic meanings of the term itself, see Sanderson (2007, pp. 370-383). The pre-eminent concern of this essay, 'nondualistic' or 'nondual' (advaita) Śaivism of Kashmir, will be referred to simply as Kashmir Śaivism or even as Śaivism (and the corresponding adjectives) unless the context requires more precision.

2 I shall refer to the edited text and the translation of PS and PSV given in Bansat-Boudon and Tripathi (2011).

3 Namely: the 'impurity of [deeming oneself] finite' for ạnavamala, the 'impurity of [regarding the world as] objective' for māyiżamala, and the 'impurity of [supposing oneself the agent of] actions' for kārmamala.
} 
From the beginnings of the exegetical period of nondualist Kashmirian Śaivism, we find terminological metaphors in, for instance, a notion that has given its name to one of the two main schools of the system, namely, spanda, literally 'vibration', 'pulsation', but employed as a designation for the supreme principle, conceived of as pure Consciousness animated by Śakti, its Energy. ${ }^{4}$

The translator of the Śaiva corpus is thus more than once required to face the question of whether to preserve or not the original metaphor. There is, of course, no single answer to this question, as will be developed in what follows.

\section{A Paradoxical Conception of Cit, 'Consciousness'}

\section{Cidrasa, 'Fluidity of Consciousness' vs. Cidghana, 'Mass of Consciousness'}

In their attempts to convey the notion of cit, 'consciousness'-fundamental in the system-Śaiva texts oscillate between two opposing analogies, on the one hand, viewing cit as rasa, 'sap', 'fluidity', on the other, as ghana 'mass'. These opposites nevertheless coincide in the notion that cit is the 'source', whether fluid or compact, of every existing thing.

Despite this rivalry, the "dense" analogy of cit as ghana (with its many variants) predominates as a topos in the texts. One observes even a kind of specialization attaching to each image, cit as rasa occurring when a contrast with the notion of the Lord as jaganmūrti, 'embodied in the shape of the world', is at issue-in accordance with the inner logic of the Pratyabhijñā system, which justifies the materiality and multiplicity of the phenomenal world in terms of a unique reality, cit, manifested therein.

Such a notion of manifestation, or crystallization, of a deity who is consciousness is made necessary by the nondualism of the doctrine itself, which in its own terms is a svātantryavāda, a 'Doctrine of freedom'. Indeed, no gross determinism is implied by this solidification of consciousness, but rather the Lord's free and sovereign, indeed playful, ${ }^{5}$ will to manifest himself without precondition, almost whimsically, in the manner of a ray of light or a bolt of lightning (hence the ubiquitous usage of roots such as sphur, sphut, etc; see infra, p. 49). The Lord's freedom is itself the one cause of phenomenal manifestation.

The idea of consciousness as fluidity crystallized in the world of phenomena appears in texts like Kșemarāja's auto-commentary on Pratyabhijñāhrdaya [PH] 4, pp. 55-56:

\section{śrīparamaśivah [...] cidrasāśyānatārūpāśsșatattvabhuvana-}

bhāvatattatpramātrādyātmatayāpi prathate /,

'Paramaśiva [...] manifests [lit., 'displays'] himself both as the totality of principles, worlds and entities and as their respective experiencers, that are only a solidified form of the essential fluidity of consciousness. ${ }^{6}$

\footnotetext{
${ }^{4}$ On spanda, see infra, p. 76.

5 It is the recurrent notion of krī mangala verse, quoted infra, p. 43.

${ }^{6}$ Unless otherwise noted, all translations are mine.
} 
The image is fully developed in the Cicchaktisamstuti, a non-Saiva text, ${ }^{7}$ which is nevertheless quoted in the Spandapradīpika $[\mathrm{SpP}]$, Utpalavaiṣnava's commentary to the Spandakārikā [SpK], which uses the same terminology:

prāśyānaś cidrasasyoghah sākāratvam upāgatah /

avaśyāyah prabodhārke tūdite svasvabhāvabhāk //,

'The stream of the essential fluidity of consciousness solidifies, assuming [concrete] forms. However, it recovers its own essential nature [i.e., its fluidity], as does the morning dew, when the Sun of consciousness rises. ${ }^{8}$

Kṣemarāja’s Spandanirṇaya [SpN] I 2 also makes use of the metaphor:

tato 'yam cidātmā bhagavān nijarasāśyānatārūpam jagad unmajjayatīti yujyate,

'Therefore, it is perfectly valid to say that the Lord who is consciousness brings about the emergence of the world by solidifying his own essence.'

Thus, consciousness (or the Lord), when oriented toward objectivity in the process of bhedavyakti, 'manifestation of difference', is described in terms of a gradual solidification, or crystallization, which process ends with the grossest element, prthivitattva. This process is emphasized through terms such as śyana (or āśyāna, or prāśyāna) and mürti, which latter, even in its common acceptation, 'form' or 'image', signifies also the materialization of the essential universality of the divinity, as confirmed by the usual derivation from the root mürch, 'solidify', 'coagulate'.'

\section{Cidghana, 'Mass of Consciousness'}

The Paramārthasāra itself does not use the term cidghana, or its variants. Rather we find (v. 35) the upanișadic and vedāntic concept of jñannaghana-the source being emphasized even in Yogarāja's avataranikīā [avat.]. ${ }^{10}$

It is Yogarāja himself who employs the term in his very first mangala verse:

cidghano 'pi jaganmūrtyā śyāno yaḥ sa jayaty ajaḥ /

pracchādanakrị̣̂̄idagdhah parameśvarah //,

\footnotetext{
7 Its author, Yoginātha, could have been a non-sectarian Śākta, whose syncretic exposition attempts to integrate both the Vaiṣnava and the Śaiva points of view; see Dyczkowski (1992, p. 290).

8 Śâstrî Islâmpurkar (1898, p. 6).

${ }^{9}$ In $m \bar{u} r c h$, the element $-c h$ is the inchoative suffix aggregated to the root by the Pāninian tradition-the primary root being *mūr, 'to stiffen up', 'to harden', which is not attested in Sanskrit as a verbal root, but is present in such nominal derivatives as mūrti, 'form', or mūrkha, 'stupid'.

10 vedāntabhāṣäbhih [...], 'by reference to language taken from Vedāntic [i.e., Upaniṣadic] statements'-be the compound taken as a tatpurușa-, or 'by reference to commonly used languages and also to Vedāntic statements (the latter drawn from certain Upanișads)—be the compound taken as a dvandva. The term 'vedānta' here presumably refers to the Upanișads directly, rather than the late Vedānta, as one of the six darśanas; and bhāṣa rather translates as 'worldly' language, which are multiple, as opposed to Vedic-Upanișadic language. This then would presumably be a dvandva.
} 
'To the One who, although nothing but a mass of consciousness, is yet solidified in the form of the world, to the unborn One who is proficient in the play (krị̂a) of concealing his own Self, glory to this Supreme Lord.'

Note that this usage deviates rather from the principle enunciated above, where cidrasa was contrasted with jaganmürti: in this case, the text associates "massiveness" with both cit and jagat, ghana to the former, mürti to the latter. The connotations are however different - the "massiveness" of cit implies its uniformity and homogeneity rather than its material "solidity". This compactness, which, understood ontologically, is animated by the subtle pulsation (spanda) of sakti, is as well the efficient cause of that other compactness, the phenomenal world (jagat), now patently endowed with the discursive dynamism of the unfolding thirty-six tattvas.

I have opted to translate the image, much exploited in nondualist Kashmirian Śaivism, of consciousness as 'solid' or 'compact' (ghana) more or less literally, though it probably seems quite paradoxical to the Western reader, as 'solidity' is normally associated with physical objects, especially weighty ones, not with events of the mind. But it also appears to be the case that Śaiva authors were quite aware of the paradox as well, and had good reason to stress it. Even in modern Sanskrit, the term ghana continues to be associated with the gross, rather than the subtle, as for instance 'ice' is commonly referred to as 'ghanibhütam jalam'.

Several rationales can be adduced for this unusual metaphorical usage, among them the fact of paradox itself, which may serve (as it often does in Advaita and Mādhyamika explanations) to shock the mind out of its usual habits and to prepare it for unexpected insights.

It may also be the case, especially for nondualist Śaivas-who do not dismiss the "solid" world as a purely illusory phenomenon (as is usually done by Advaitins, and even more radically by Vijñānavādins), ${ }^{11}$ but see it as an activity of the Lord himself - that, by this paradox, attributes normally associated with the effect are transferred to the cause, emphasizing thus the cause's truly substantial reality.

The figure underlying the usage is then a kind of hypallage, an exchange of qualities between the world and consciousness. Thus the substantive ghana functions as a kind of epithet transferred from the world to consciousness.

Which suggests a third rationale for the usage: namely, that what is at issue here are the connotations suggested by 'solidity' in its literal sense: consciousness is 'compact', 'uniform', 'pervasive', etc.

And finally, in stressing what amounts to the materiality of consciousness, Pratyabhijñā authors may be making a point that is often associated with the 'material cause' (in Aristotelian terms), namely, that, quâ matter, all form is superadded and ipso facto extrinsic. As Chāndogyopanișad [ChU] says, what is 'real' is the clay, not the pot or the dish or the toy formed of it. Mutatis mutandis, the clay (as matter) is 'inexpressible' except as or through form-one cannot encounter clay as such, and yet all clay objects are nothing but clay. ${ }^{12}$

\footnotetext{
11 See infra, p. 54ff.

12 It is Uddālaka's discourse on the unity of Being (ChU VI 1, 4ff.): yathā saumya ekena mrtpinḍena sarvam mrnmayạ̣ vijñātam syāt vācārambhaṇam vikāro nāmadheyam mrttikety eva satyam, 'Just as, my dear, by one clod of clay all that is made of clay becomes known, the modification being only a name arising from speech while the truth is that it is just clay' (transl. Radhakrishnan).
} 
Taken together, these interpretive possibilities present a strong justification for this apparently anomalous metaphor.

However that may be, the formula does have Upanișadic antecedents, such as prajñānaghana or vijñānaghana, 'massive cognition (or 'consciousness')' applied to brahman or àtman; for instance in Brhadāranyakopaniṣad [BĀU] IV 5, 13: evam $v \bar{a}$ are 'yam àtmā [...] krtsnah prajñānaghana eva, ${ }^{13}$ and II 4, 12: idam mahad bhütam [...] vijñannaghana eva, ${ }^{14}$ where the connotation to be derived from the parallel analogy of the mass of salt (saindhavaghana or saindhavakhilya) dissolving in water is that of the immateriality and pervasiveness of what is diluted thereinthe same paradoxical formulation aiming at expressing the inexpressible.

Likewise Ágamaśāstra [ĀŚS I 1 uses the term ghanaprajña ${ }^{15}$ and PS 35 (as well as Yogarāja, its commentator) that of jñ̄naghana, with a slightly different implication, due to the context, which is that of the four avasthās.

Thus, in order to emphasize the paradox inherent both in the form and the doctrine, I prefer maintaining the metaphor, and will translate the binary compound cidghana as 'mass of consciousness'. An alternative translation, less literal, yet expressing more directly the metaphysical force of the notion would be 'unalloyed consciousness' - although the metaphor, drawn from metallurgy, is perhaps more specific to English.

It will be noted that, here and there, I have translated these notions somewhat more freely to avoid burdening the reader with so many "massive" constructions, and to suit the English syntactical context-for example, PSV 6, for the compound cidekaghana:

tathaivāyam is varah svatantraś cidekaghanah [...],

'Likewise, [as the crystal-gem may contain a variety of colors] so the Lord, free, solely formed of consciousness $[\ldots],{ }^{16}$

or PSV 67:

aham eva cidghanah,

'I am indeed formed [entirely] of consciousness.' 17

\section{Cidānandaikaghana, 'Uniform Mass of Blissful Consciousness'}

The compound cidghana is a nucleus to which other units may be added, by a process that is, in principle, unlimited. In such cases, the core metaphor is preserved at all costs, even though the translation of the expanded compound cannot always be a matter of simply adding determinations - whether substantival or adjectival-to

\footnotetext{
13 Radhakrishnan translates by: 'mass of intelligence', resting his choice on the preceding images, saindhavaghana, etc.

14 Again compared to the lump of salt (here, saindhavakhilya)—which obviously takes up again the theme developed in the Chāndogyopanișad.

15 Bouy (2000) translates: 86: 'masse de pure conscience objectale'.

16 Lit., 'a mass solely consisting of consciousness'.

17 See also PSV 74.
} 
the base unit. The meaning of the long compound cannot be deduced from a linear reading of its discrete elements.

cidānandaikaghana, an expanded form of the kernel cidghana, is a recurrent term in Yogarāja's commentary. Its first occurrence is found in the avat. ad PS 1:

\section{parimitapramātrtādhaspadīkāreṇa cidānandaikaghanasvātmadevatāsamāveśaśālinīm samastaśāstrārthasaṃkṣepagarbhām prathamas tāvat parameśvarapravanatām parāmrśati,}

'[The author] first considers his reverence to the Supreme Lord. The essential meaning of the entire treatise is inherently present in this reverence, and it is through this reverence that is enabled absorption in the divinity who is but one's own Self, a uniform mass of blissful consciousness (cidānandaikagha$n a$ ), once the condition of finite cognizer has been overcome.'

The compound may be literally understood as 'mass consisting solely of consciousness and bliss' (if the compound cidānanda be understood as a dvandva, as is generally the case); or 'mass consisting solely of the bliss that is consciousness' or 'mass consisting solely of the bliss of consciousness' (if the compound be understood as a karmadhāraya or tatpurușa).

An inventory of more-or-less equivalent expressions gleaned from the commentary (cidekaghana, cidekavapus, cidekamūrti, cinmūrti, cinmūrtatva, cinrūpa, citsvarūpa, cidghana, abhinnacidghana ${ }^{18}$ ) suggests, beneath the diversity of style, as noted above, that what is being emphasized here is i) the sole reality of cit (by appropriating qualifications normally associated with its objects, viz., ghana, vapus, mürti, rūpa, etc.); ii) the materiality of cit, as the sole basis of the visible world.

The mention ananda in the longer versions of the compound seems destined to add a sensory dimension to that uniqueness.

All of which might be alleged to favor the interpretation of the compound itself, not as a dvandva, but as a karmadhäraya or tatpurusa-for, precisely, cit and ananda are not separable (see also, infra, the reasoning on anavacchinnacidānandaikaghana); hence my translation: 'a uniform mass of blissful consciousness'-an understanding which appears to me to be more in line with the basic purport of a nondualistic doctrine such as the Trika, rather, the last stage of the Trika, as expounded by Abhinavagupta. ${ }^{19}$

The Trika may, as well, be distinguished from the more austere currents of Advaita Vedānta in its more positive evaluation of the perceptible world, culminating in a sense of marvel (camatkāra), a 'marveling' that borders always on joy (ananda), and characterizes both the regard the yogin casts upon this marvelously variegated world and the open-eyed delight with which he contemplates his identity with that world and with the Lord-a posture which has, in this

\footnotetext{
18 avat. ad 46: 'abhinnacidghanaśiva : 'Śiva, formed of undifferenciated consciousness'.

19 It is an old question, with which Advaitins and their opponents have dealt ad libitum: how to maintain the unicity of brahman while attributing to it several epithets, such as sat, cit, ānanda? See also infra, p. $73 \mathrm{ff}$.
} 
system, aesthetic implications. ${ }^{20}$ In this case, the novelty lies not so much in the vocabulary, or the ideas taken separately, as in the rather paradoxical spirit of synthesis that tries to incorporate into a monistic system concrete aspects of the real world, and to highlight them within it-hence the quasi complete borrowing of the Sāmkhya cosmology (upon whose twenty-five tattvas is superimposed a specific Śaiva aparatus of eleven additional tattvas), and the will to use enjoyments proper to the body itself (theatre, tantric practices, etc.) as a propaedeutics for spiritual realization.

PSV 33, in the context of describing the yogin (alias the jivanmukta, 'liberated while living ${ }^{21}$ ) who has sloughed off the conceit that takes the body to be the Self (dehādyabhimāna) and reaches to the 'marvelous form of supreme ipseity' (parāhantācamatkārarūpa), observes:

cidānandaikaghanaḥ svatantro 'smi,

'Then he knows: "I am a uniform mass of blissful consciousness, [hence] I am free".'

-a text which offers also an occasion for noting the frequently occurring association of the terms cidānandaikaghana and svātantrya, 'freedom' (see also, infra, PSV 39, quoted p. 47ff).

Three variants are found, each developed from the base cidanandaikaghana:

Pūrnacidānandaikaghana, 'Uniform Mass of Blissful Consciousness That is Ever Complete ${ }^{22}$

The compound is to be found in PSV 33:

iti prākpratipāditena krameṇa bhagavān svatantrạ̣ paramaśivaḥ

pūrṇacidānandaikaghanalakșaṇah [...] bandham vidadhāti,

'Thus, i.e., through the process expounded earlier, the free Lord, the Supreme

Śiva, whose distinguishing feature is that the uniform mass of blissful consciousness of which he is composed is ever complete [...], creates bondage.'

\footnotetext{
${ }^{20}$ See Bansat-Boudon and Tripathi (2011, pp. 55-56).

21 On this notion, and on the Paramārthasāra as a treatise mainly dealing with jīvanmukti, see BansatBoudon and Tripathi (2011, pp. 32-48).

22 Or: 'uniform mass of blissful and ever complete consciousness'. The compound is for the most part understood as a bahuvrīhi, lit., 'whose uniform mass of blissful consciousness is ever complete'. Yogarāja ad PS 1, glosses para, 'transcendent' as purṇa 'full', which he further explains as: param pürṇam cidānandecchājñānakriyāśaktinirbharam anuttarasvarūpam, '[The Lord who is] replete with all five energies-Consciousnes, Bliss, Will, Knowledge and Action-, and who has thus the nature of the Unsurpassed.' Same exegesis in PSV 43 (Bansat-Boudon and Tripathi 2011, p. 201). The term pürṇa is used elsewhere as an epithet for brahman - in the Dvaita school, for instance - to point out the error inherent in the notion of the Absolute that is commonly attributed to Advaitins: brahman is not devoid of qualities (nirguna); rather, it possesses them all (saguna), even those that the common man fails to imagine. It is to be assumed that the epithet pürṇa has become customary in anti-Śankarian systems, of whatever monist or dualist persuasion (although the opposition is somewhat artificial).
} 
Paramādvayacidānandaikaghana, Uniform Mass of Blissful Consciousness, Supreme and Nondual'

\section{As in PSV 18:}

asau mārgah paramādvayacidānandaikaghano 'smi [...] yā svātmasvarūpavibhūtipratyavamarśarūpā saraṇiḥ [...],

'The path, that is, the method whereby one arrives $a^{23}$ the awareness that one's own essence is resplendence (vibhüti), which takes the form: "I am a uniform mass of blissful consciousness, supreme and nondual" [...].'

Anavacchinnacidānandaikaghana, 'Undifferentiated Mass of Uniform Blissful Consciousness, 24

This is another recurrent variant, as in PSV 29:

\section{na punạ̣ paramārthataḥ svātmano 'navacchinnacidānandaikaghanasya} dharmādharmādikam kimcid vidyata iti,

'However, merit and demerit, etc., do not exist ultimately for the Self, which is an undifferentiated mass of uniform blissful consciousness.'

The epithet avacchinna is here understood in its scholastic sense of 'differentiated', 'qualified', 'conditioned'-the avacchedaka being the quality or particularity that distinguishes one individual (or type) from another (as its dewlap differentiates the Indian cow from other animals). The term anavacchinna here indicates that the terms cit and ananda are in this sense not to be differentiated, inasmuch as they cannot be limited by anything whatsoever, including each otherthey are the absolute itself; supposing otherwise would contradict their absoluteness. $^{25}$

See the use of the positive avacchinna in PSV 58:

sarvam hy abhimānasāram kāryatvena pratibhāsamānam idantāvacchinnam utpadyate kșīyate ca,

'For everything that appears as something to be effected or is determined [or qualified] (avacchinna) as "this" or "that" [viz., as ecceity]—[everything] whose essence is conceit of self (abhimāna) — originates and perishes.'

We find also a variant in PSV 39, where anavacchinna occurs outside the compound at issue:

ahạ̣ cidānandaikaghano 'navacchinnasvabhāvaḥ svatantraś cety akritrimāhantāsphuranayā,

\footnotetext{
23 Lit., 'whose form is ...'.

24 Cf. PS 29 in Bansat-Boudon and Tripathi (2011, p. 164), where I proposed a variant: 'uniform and unqualified mass of blissful consciousness', in which anavacchinna is rendered as 'unqualified'-a variant that can nevertheless be considered to put too much emphasis on the strength of 'eka'.

25 Note that a similar problem is resolved in the Advaita Vedānta in a similar way.
} 
'[...] thanks to the irruption (sphuranāa) [into consciousness] of nonadventitious ipseity, such that one now judges: "I am a uniform mass of blissful consciousness; my nature is unconditioned (anavacchinnasvabhāva); I am free" [...].'

\section{Sphurattā and Bhavanakartrtā}

The idea that the sovereign exercise of the Lord's essential freedom is experienced as 'play' (krị̂a $)$ and assumes material form as palpable manifestation has as its corollaries two notions that nondualist Śaiva texts present as closely related: sphurattā (with its doublets, sphurattva, sphurana(-ṇā), etc.) and bhavanakartrt $\bar{a}$ - which one might even consider quasi-synonyms for they intend to explain the same (idea of) reality, which conforms to the dynamic ontology of the system.

They are nevertheless, at first sight, different notions by virtue of their derivations: the former, an analogy based on the primary meaning of the root sphur; the latter, an abstract noun formed from the agent noun (kartr, 'doer') derived from the universal" verbal root $k r$ ('to do'), as modified by an action noun (bhavana) derived from the "universal" stative verb $b h u$, 'to be', 'to become'. Those roots are understood as "universal" (although with some reservation about the root $b h \bar{u}$; see n. 28) according to Pāninian grammatical philosophy, which considers that every verbal root divides into two elements that are called vyāpāra, 'activity', 'effort', 'function', and phala, 'fruit'. Similarly, Mīmāmsaka grammar sees in every verbal ending (common to all verbs) the evocation of a generalized transformation that expresses itself abstractly by means of the root $k r$, which conveys the verbal idea as such (see the Mīmāmsaka analysis, yajate = yāgam karoti). Vyāpāra is therefore nothing else but the effective or transforming power, which, under a given circumstance, produces the expected result $($ phala $){ }^{26}$ As such, this power is equivalent to the abstract meaning of the root $\mathrm{kr}_{0}{ }^{27}$

It may be concluded that the compound bhavanakartrta merges the two most general verbal ideas, those of the "verb" (expressing change), namely $k r$, and of the "non-verb" (expressing the unchanged condition), namely $b h \bar{u},{ }^{28}$ so much so that,

\footnotetext{
${ }^{26}$ See a later work, Nāgeśa's Paramalaghumañjūṣā [PLM], accounting for the Mīmāṃsaka position (p. 85): phalānukulo yatnasahito vyāpāro dhätvarthah [...], 'The meaning of the verbal root is an operation (vyāpāra) conducive to the production of a result (phala) and accompanied by a volition or effort (yatna)' (transl. K. Kunjunni Raja, in Coward and Kunjunni Raja (2001, p. 330).

27 My understanding of the topic has greatly benefited from a thorough discussion with Edwin Gerow.

${ }^{28}$ It is noteworthy that some grammarians treat the root $k r$ ('to do') as what could be called a "generalized verbal root", but not the root $b h \bar{u}$ ('to be'), which they somehow consider as a suspect root, inasmuch as it does not express a transformation and its object remains in the nominative, and could thus be conceived of as the "non-verb"; on this suspicion, see the modern commentary of Kalikaprasad Shukla ad PLM: nanv evam astyādīnām dhātutvānāpattis teșām sattāmātrārthatvena vyāpārarūpakriyāvācakatvābhāvād ata āha [...], quoted infra, p. 73. That the root $k r$ may be considered as the generalized verbal root is further evidenced by grammatical terminology itself: kriyāa(pāda) is the 'verb' seen as an 'action'; the kārakas (or 'notions of a case') are the very notions of the syntactical relations between the verb and the noun, by which is realized the potential sense of the root (on kärakas, see infra, p. 70ff); the 'subject'
} 
whereas sphurattā functions immediately as a quasi-poetic term, bhavanakartrtā contains in its very formation the elements of a philosophical discourse: it is the 'quality of being the agent of being' — viz., the agency implicit in what is, will be, or has been.

In other words, the nominal composition articulates the intimate connection of doing and being, making the supreme principle-Consciousness as deity-the agent of both being and becoming; it thus epitomizes the salient feature of this system, namely that this Agent, the Subject par excellence, is that cause or source of that which, from the point of view of the bound paśu, appears to be other than subject. Such an Agent, so comprehended, is, in fact, the entirety of the phenomenal world, which has taken on the appearance of exteriority. In the dynamic ontology of such a nondualism, the Subject must be an Agent, inasmuch as the external world is his work, rather, himself as so manifest. I shall take up the issue again while examining bhavanakartrtā.

\section{The Sememe of Light: The Root Sphur and Other Related Verbs}

Mayrhofer, Monier-Williams, and other authorities consider the roots sphur, sphar, sphāy, sphut more or less related; the various senses that may attach individually to each root are often confounded in the usage of the others-extending from 'be enormous' to 'explode', and including, by semantic extension, such senses as 'blossom', 'shine forth', 'flash forth' and 'vibrate'.

On the other hand, all of the roots [pra-]kās', [pra-, vi-, ava-]bhā, bhās, sphur, sphut, sphar, etc.- -which occur with great frequency, given the importance of the notion of light in this doctrine-appear to be employed without major differentiation of meaning. ${ }^{29}$

Given these considerations, I have preferred to render these terms more or less indifferently with translations such as 'appear', 'emerge', 'become evident',

\section{Footnote 28 continued}

is the 'agent': kartr; that by which an action is effected, mainly the instrumental case, is karana, etc. Ultimately, nevertheless, orthodox tradition (as reflected in PLM quoted infra, p. 72: astibhavativartatividyatīnām arthah sattā [...] satteha ätmadhäranam) accepts the "verbality" of the roots as and bhü, 'to be', for a certain effort is required to continue in the same state, to persist in one's own being; on this question, see also infra, p. 73ff.

29 See especially Jayaratha's Tantrālokaviveka [TĀV] ad TĀ V 123, where, applied to Śakti and its manifestation of the universe, the terms bhāsate, prathate and sphāra (in viśvasphāra) are equivalent: atrānandapūrṇe dhāmni asaṃkocavikāsino nistarañgajaladhiprakhyasya pūrṇasya prakāśasya sasaṃkcavikāsikā sadaiva srșțisaṃhāramaȳ̄, ata eva durghațakāriṇ̄ svātantryākhyā śaktị̆ bhāsate svātmaikātmyena prathate, yan māhātmyādiyān viśvasphāraḥ sadaiva srsștisamhāradaśādhiśāyitām etīty arthah, " "There" [means] in that place overflowing with delight;-_[Bhairava] who never expands or contracts" [refers to] all-encompassing Light, said to be [like] an ocean without waves;- - "in expansion and contraction" [means] eternally composed of creative and destructive [forces].-For this very reason, [his] "energy" [is said to] "accomplish the impossible", in virtue of which it may also be termed "freedom";-[and so, that energy] "manifests itself" (bhāsate), [that is] it extends itself (prathate) [as everything visible] inasmuch as it is [ever] identical with itself [viz., incapable of abolishing its own nature]'-because of whose grandiose work, the emergence of the universe (viśvasphāra) [is attested] in such a form (iyān-viz., "takes on the limited form that we apprehend"), eternally tending toward being governed by conditions of creation and destruction'. 
'become patent', 'be present', 'manifest', 'become manifest', etc. While these terms may seem rather anodyne, my goal has been to privilege a more philosophical rendering, one that is better suited to the philosophical context and argument, whereas the more literal translations, 'shine forth', 'surge forth' (or 'fulgurer' in French), etc., give, in my view, too much weight to the underlying metaphor.

Indeed, the metaphor cannot be wished away, inasmuch as variations on the idea of luminosity are an essential feature of the doctrine, as illustrated by the famous dictum:

nāprakāśạ prakāśate,

'That which is not luminous cannot manifest itself, ${ }^{, 30}$

or the maxim recurrent in nondualist Śaiva texts :

sakrd vibhāto 'yam ätmā, (or even: sakrd vibhātah),

'The Self has appeared once (and for all).' 31

These are as many formulae, Upanișadic antecedents of which can be found, as for instance Śvetāśvataropaniṣad [ŚvU] VI 14:

na tatra sūryo bhāti na candratārakam nemā vidyuto bhānti kuto 'yam agniḥ /

tam eva bhāntam anubhāti sarvam, tasya bhāsā sarvam idam vibhāti //,

'The sun does not shine there nor the moon and the stars, nor these lightnings, much less this fire. After Him, when He shines, everything shines, by His light all this is illumined. ${ }^{32}$

Still, the analogy of luminosity, perhaps because it is not reinforced by an intentionally driven paradox, as is the case with cidghana, turns out to be largely ineffective if literally rendered.

In any case, the analogy itself as well as its more or less literal translations long misled me as I began pondering the Śaiva corpus. What did phrases such as 'The Lord shines forth, etc.' really signify? The image, of course, was more or less confusedly perceived, but what were its function and meaning within the philosophical discourse? The propositions made earlier attempt to answer the question.

It is no less legitimate, though, that many specialists should retain (some quite insistently), the original metaphor, insofar as it cannot be denied that these roots,

\footnotetext{
${ }^{30}$ Lit., 'the absence of light cannot itself shine forth', quoted in Yogarāja ad PS 30. In other words, consciousness contains everything within its fold; that is, apart from consciousness, nothing can be conceived. Whatever is not an object of knowledge does not exist-moreover, the very idea of something that 'cannot be known' is self-contradictory. See also ĪPK I 5, 3: bhinne prakāśe cābhinne saṃkaro vișayasya tat / prakāśātmā prakāśyo 'rtho nāprakāsáśs ca sidhyati, 'If light were undifferentiated (in itself) and differentiated (from objects), then objective reality would be confused. The object that is illuminated must itself be light; that which is not light cannot be established.' (transl. Torella 1994).

${ }^{31}$ The maxim is quoted in PSV 11. It is an abridged form of sakrd vibhāto 'yam ätma pūrnasyāsya na kväpy aprakäśanasambhavah, 'Once this Self has appeared [, its possibility of not appearing is nowhere (i.e., is not possible), for it is complete,' quoted by Abhinavagupta in his I'svarapratyabhijñavvivrtivimarśin $\bar{l}$ [İPVV] II 1, 6-7 (vol. 3, p. 23), and attributed to the Śaiva Sārasvatasamgraha. On the notion and its non-Śaiva antecedents, see Bansat-Boudon and Tripathi (2011, pp. 13-14, and 110-111) (n. 455).

32 Transl. Radhakrishnan (1978). Also, Muṇdakopanișad [MuU] II 2, 11, Kathopanișad [KU] II 3, 15.
} 
most notably sphur, sphut, etc., do connote light or illumination, itself taken to imply a vibration, a pulsation ${ }^{33}$ - an active phase unknown to the rival nondualism, the Advaita Vedānta.

Yet, the various periphrases that are used for rendering sphurattā, such as 'the luminous vibrating' (or 'the shining-vibrating') ${ }^{34}$ are at least flawed by seeming quite unnatural in the language of translation. The flaw might somewhat be mitigated if a verb could be found corresponding to the French 'fulgurer' - which conveys the two meanings at issue and can be glossed accordingly, and thus offers a suitable translation of these Sanskrit terms. (The English version of this verb, 'to fulgurate' is of little help, being both exceedingly arcane and limited to senses based on its Latin etymology, to 'behave like lightning'; see Oxford English Dictionary.) But whether in French or in English, adopting a literal translation of the metaphor would incur the risk, already mentioned, of diverting the reader's attention from what is philosophically at stake in such usages. A further argument being that one should avoid overloading this kind of technical language, when there is little risk of ambiguity for the reader. ${ }^{35}$

Therefore, I have preferred to render the expressions at issue with an equivalent that is both conceptually justified and terminologically explicit-a preference which, however, is not inflexible, and may even be disregarded at times, depending on the context and other factors, notably, the occurrence of the form at issue in prose or verse.

In effect, even a partial survey of the occurrences of the root, made at random in the texts, brings out the fact that opting for a "conceptual" translation ('appear', 'be present', 'manifest', etc.) is suitable to prose philosophical discourse, particularly exegetic discourse, notably when the context is that of the externalization of the supreme principle, of the Lord's manifestation as the external world. It is generally so in the many occurrences of sphur in the commentary by Yogarāja on the Paramārthasāra.

By contrast, in the source texts in verse, particularly when the doctrine is exposed by means of mystic references and attempts to express the ineffable, one can observe that the metaphoric use of sphur, whichever of its connotations is to be emphasized ('blossoming', 'sparkling', 'pulsation') is sometimes better able to convey its meaning.

Such is obviously the case with the related root $b h \bar{a}$, in PS $56 \mathrm{~cd}$ :

gatajanmabandhayogo bhāti śivārkaḥ svadīdhitibhiḥ //,

'Once the connection with the bondage of birth is severed, the sun of Siva shines with its rays unhindered, 36

\footnotetext{
33 See infra, spanda and sphurattā, p. 52ff.

34 Or, for the verb, such translations as 'shines-vibrates'; see Torella (1994, p. 121, and n. 28).

35 For instance, in the translation of bhāvanā, I have opted for a somewhat expanded translation, namely, 'meditative realization', for 'meditation' or 'realization' alone would not have accounted for the complexity of the notion; see infra.

36 Lit., 'with its very own rays'.
} 
in which, while translating 'bhäti', glossed as 'sphurati', I have maintained the original image, inasmuch as svadìdhitibhih, the complement in the instrumental, makes it an extended metaphor.

Whatever may be the value of these observations, it should be stressed, however, that no constant rule can be inferred therefrom: every register shades into another, the context being, for the two languages at issue, the ultimate criterion.

\section{Sphur, Sphurattā / Sphuraṇa}

Thus, according to the context and the line of philosophical argument, the noun sphurattā ('sparkling', 'effulgence', 'scintillation', on the one hand, 'trembling', 'throbbing', 'shaking', on the other), abstract noun formed from the present participle of the root sphur, may assume, not only the philosophical meanings of 'manifestation' (rather 'capacity of manifesting [oneself as the world]'), or even 'awareness'- that 'awareness' without which no phenomenal 'manifestation' is possible -, but also, at times, any of the metaphoric connotations of the verbal root.

The comparative grammar of Indo-European contributes to the understanding of the Sanskrit root, by postulating sphur: *spherH '(mit dem Fuß) stoßen', 'to push with the foot' (Mayrhofer 1956-1980, KEWA, s. v.; Pokorny 1959, pp. 992-993; Rix (2001, p. 532), 'to make a sudden move, repel abruptly, run away', giving the Vedic sphuráti ('to make a sudden move, to move fast'), the ancient Greek $\sigma \pi \alpha i ́ p \omega$, spaírô ('to pant, to tremble') and $\alpha \sigma \pi \alpha i ́ p \omega$, aspaírô (id.), the Latin sperno, 'to move (something) away, to push aside', asper, 'uneven' (of a ground surface which 'repels' footsteps, for example), the English spurn.

The stem of this family of words seems to be *per- ('dissipate'), which produces the ancient Greek $\pi i ́ \mu-\pi \rho \eta-\mu$, pim-prê-mi, 'to burn, set on fire', the Slavonic para ('steam', 'vapour'), and which may be at the origin of the Sanskrit meaning 'to radiate'. 37

The semantic derivation, in Latin and English, which gives 'to despise' (sperno, spurn) is easy to trace from 'to push with the foot' or 'repel abruptly'. The Sanskrit acceptations, particularly the Saiva usages of the root, can be derived from the primary meaning 'to make a sudden move'; hence, the idea of 'trembling' attached to the root by Śaiva speculations, and also present in Greek $\sigma \pi \alpha i ́ p \omega$, spaírô ('to pant, tremble') and $\alpha \sigma \pi \alpha i ́ \rho \omega$, aspaírô.

The sememe of light seems to be absent from those original meanings. Yet, it could have been derived from 'to push with the foot', inasmuch as one can suppose that there has been a shift from the image of something that bursts out when being kicked (a lump of clay, an overripe fruit) to the idea of a radiance; even more, it is a trembling/pulsating radiance, according to one of the primary meanings of the root: 'to make an abrupt move', therefore, 'to tremble' (see Greek). ${ }^{38}$ Such a semantic derivation is supported by the postulated stem *per-, 'dissipate' (see above).

\footnotetext{
37 Some features of this development have been borrowed from Wiktionnaire, s.v. sperno. The rest of it is mine.

38 As for the root sphut (whose nominal derivative is sphoța), which, according to Mayrhofer KEWA, s. v., could be onomatopoeic, it is not attested outside Indo-Iranian.
} 
In any case, to understand fully the connotations of these Śaiva usages of the root requires a full exposition of Saiva doctrine-which is beyond the scope of this paper. I will therefore limit myself to a few examples likely to corroborate my initial proposition for translating sphur and related roots as 'manifest', 'appear', etc.

Thus, it is noteworthy that, in the passage of TĀV V 123 (quoted above, n. 29), where the context is a discussion of phenomenal manifestation (viśvasphāra), the form bhāsate (root bhās_-used interchangeably with the root sphur)—is glossed by prathate (root prath). Commenting on bhāsate durghatā śaktih of the verse, Jayaratha then says:

bhāsate svātmaikātmyena prathate,

'[And so, that energy] "manifests itself" [lit., 'shines forth'] (bhāsate), [that is] it "extends itself" (prathate) [as everything visible] inasmuch as it is [ever] identical with itself [viz., incapable of abolishing its own nature]. ${ }^{39}$

Similarly, TĀV IV 14 glosses the quasi-synonym sphutayet as sākṣātkuryāt, 'It should be made directly perceptible'.

In PSV, the first occurrence of the notion conveyed by the root sphur is to be found ad PS 1:

'tvam' sarvapramātrsphurattāsāram svātmadevatārūpam eva [...],

" "You", that is, one whose form is the god that is my own Self, one whose essence is that [capacity of] awareness (sphurattā) present in every cognizer [...].'

And further on, in the same passage:

[...] na punas tattadavasthāvaicitryeṇāpi sphuratas tatah parasmāt pūrṇāt svarūpāt tasya pracyāvo bhavati,

'And although he manifests himself (sphurat) in marvellously varied states of consciousness, he does not deviate from his transcendent nature, which is allencompassing. 40

Many are the occurrences of the root sphur and its derivatives in Yogarāja's commentary, especially when the exegete assays to convey the jũannin's spiritual experience, as in PS 62:

aham eva ittham viśvātmanā sphurāmi,

'It is $I$ who appear as the Self of everything'

- an experience that Yogarāja presents as the handiwork of citiśakti, the 'energy of consciousness'. 41

It is precisely while defining citi, 'consciousness', or rather 'dynamic consciousness', that Íśvarapratyabhijñākārikā [ĪPK] employs the term sphurattā for the first time (ĪPK I 5, 14).

\footnotetext{
39 See the complete text, n. 29.

40 An idea that is present in SpK I 3, quoted immediately after by PSV 1, and in PS 34.

41 See Bansat-Boudon and Tripathi (2011, p. 233).
} 
In ĪPK I 5, 13, consciousness (citi), being essentially reflective awareness (pratyavamarśa), is represented also as 'supreme Speech' (parā vāc), the 'freedom' (svātantrya) — 'in the absolute sense' (mukhyam) — and the 'sovereignty' (aiśvarya) of the supreme Self (paramātman):

citị̣ pratyavamarśātmā parā vāk svarasoditā /

svātantryam etan mukhyam tad aiśvaryam paramātmanah //.

In his Íśvarapratyabhijñāvimarśinī [ĪPV] ad loc., Abhinavagupta explains:

yā citih citikriyā tasyāḥ pratyavamarśah svātmacamatkāralakṣaṇa àtmā svabhāvah,

'By citi, he means the activity that is called citi (citikriyā), whose essence (ātman),

i.e., nature, is the capacity of self-reflection [or: is reflective awareness]

(pratyavamarśa), characterized by one's capacity of marvelling at one's own Self.'

In the following verse (İPK I 5, 14), citi is again described as sphurattā, the 'manifestation', or rather, the 'capacity of manifesting [the world]', mahāsattā, the 'absolute being', and hrdaya, the 'heart', of the Supreme Lord:

sā sphurattā mahāsattā deśakālāviśeșiṇī /

saișā sāratayā proktā hrdayam parameșthinah //.

Those so-called equivalents enumerated in ĪPK I 5, 13-14 are in fact autonomous concepts, which would deserve an individual and thorough treatment, even though they function as closely related within a very well-knitted conceptual web. ${ }^{42}$

It is not here the place to do so. I will only underline that the use of the root sphur in the sense of 'manifest' is significant, for the Trika's phenomenal world is not an illusory appearance (vivarta), as some Advaitins hold, while making it the handiwork of $m \bar{a} y \bar{a}$, and, as also claimed, even more radically, by the Vijñānavādins, who altogether deny the reality of the empirical world; nor is it a real transform (parināma), as stated by followers of the Sāmkhya and the Pāñcarātra, and with reservations by the Bhāmatī school of Advaita-the latter rejecting both the "idealism" of the vivartavāda and the extreme "realism" of the parināmavāda, while attributing a conditional, namely, non-absolute, reality to the world of experiences. ${ }^{43}$

Rather, in the Trika, that world of experiences is but the luminous manifestation of the Lord (or spanda principle) that is implicit in every act of consciousness and which 'surges forth' periodically as the insight determining even the possibility of awareness. Moreover, as we shall see below (see Chart), Utpaladeva's Vrtti glosses sphurattā as bhavanakartrtā, which implies in all probability, at least in this context, the Lord's capacity of manifestation.

It should be noted, however, that occasionally the context in which the root sphur and its derivatives are used, as well as certain requirements in the syntax and lexicon of English, or the content of commentaries have suggested that I should maintain some trace of the original metaphor, as, for instance, in TA IV 184-186a:

\footnotetext{
42 See infra, p. 76.

43 Reference is made here to the "reality" subordinated to the law of causality, inasmuch as the "reality" of every thing is determined by the conditions presiding over its advent.
} 
kimciccalanam etāvad ananyasphuraṇam hi yat /,

'[That pulsation (spanda) $]^{44}$ is imperceptible movement, autonomous scintillation (sphurana).'

The verse seems to emphasize the autonomy of the movement, which results in the phenomenal appearance: spanda is a certain sort of movement that has no other source than itself, which is independent of any condition whatsoever.

Thus, spanda and sphurattā are made more or less synonymous, exchanging their respective qualities of luminosity (sphurattā) and dynamism (spanda) ${ }^{45}$ - the main purport of both notions consisting probably in their conveying the autonomy and spontaneity of that very first (and divine) ${ }^{46}$ movement that is the only cause of phenomenal appearance. As noted in Jayaratha's commentary, which glosses explicitly 'sphuraṇa' with 'prakāśa(na)':

[...] ananyāpekșam sphuraṇam prakāśanam / parato ’sya na prakāśah api tu svaprakāśa evety arthah / idam eva hi nāmāsya jadebhyo vailakșanyam /, '[...] autonomous "scintillation" (sphurana) means "light"; not the light emanating from another, but that emanating from oneself-this is the purport. It is that indeed which distinguishes [the deity whose spanda manifests the world] from inanimate entities.'

Elsewhere, where the context is not that of the Lord manifesting himself as the external world, but that of describing the inner experience of the jñanin, I have translated sphurana as 'irruption', retaining one of the connotations of the original image, namely, the suddenness and spontaneity of appearance implied in such terms as 'explode', 'surge forth', 'flash forth', etc. (cf. PSV 39, cited supra, p. 47)

Another example can be found in the first line of TA I 1 -an eminently esoteric one, which, with much resort to ślesas, offers a condensed version of the Trika's metaphysics, intimately permeated with mystical approach. ${ }^{47}$ There the devout wish of the author, Abhinavagupta, is that his 'heart should burst out' (samsphuratāt) in the overpowering fervour of mystic attainment:

\section{[...] hrdayam [...] mama sampshuratāt.}

How to translate this? 'Let my heart burst out!', 'let my heart shine forth!'? ${ }^{48}$ Whatever the case may be, Jayaratha glosses samsphuratāt, a rare imperative form, by the imperative of the root vikas, 'blossom':

\section{[...] kālatrayāvacchedaśūnyatvena vikasatāt,}

\footnotetext{
44 A spanda described as svātmany ucchalanātmakah, 'That which springs upward in one's own self', in the previous verse (TĀ IV 183); on spanda, see infra, p. 75.

45 This is further evidenced by the fact that Abhinavagupta, when commenting on the sphurattā of ĪPK I

5,14 , does not explain that very notion, but, in great detail, that of spanda (see, infra, p. 76).

46 It amounts to being the 'play' (krị $\bar{a} \bar{a}$ ) of the God, as the expression of his sovereign freedom.

47 Same opening verse in all but one of Abhinavagupta's expositions of the Trika; for a translation and a detailed interpretation of it, as occuring in the Tantrasāra, see Sanderson (2005), who does not examine the meaning of sphur.

48 Sanderson (2005, p. 89) translates: 'May my heart shine forth'.
} 
'[...] let it blossom, since it is exempt from the division of the triple temporality.'

Yet this is only the first layer of meaning. Indeed, further on (KSTS, p. 8), Jayaratha again describes that 'heart' as 'prasphuradrūpa', 'radiant', 'sparkling', and develops the content of the intimate substance of that spiritual experience, in which the 'heart' refers this time to the indissoluble Śiva/Śakti dyad. So much so that, Jayaratha concludes, hrdayam [...] mama sampshuratāt is a way, for Abhinavagupta (as for the deity that he does not differ from), to say: tādātmyenaikah syām, 'May I be one, by virtue of the coexistence [of the śaktis with myself].'

Jayaratha explains (p. 4-5) another occurrence of sphur in the same first verse, namely the compound sphuritabhāva, 'of a scintillating nature', an epithet for the creation, in the sense of procreation (lit. 'emission', visarga) of the phenomenal world by the divine couple, Śiva-Śakti (alias, through śleșas, Abhinavagupta's mother and father, Vimalā and [Nara]siṃhagupta; see Sanderson (2005, pp. 89, 137, 139)

This time he glosses the root sphur by the root ul-las, whose primary sense is 'shine forth', 'beam', 'radiate', and therefore metaphorically means 'come forth', 'appear', 'become visible', but, just like other roots conveying the meaning of light (such as sphut, a derivative of which is the term sphota), also connotes the idea of resonance. To those meanings of $u$-las are added the acceptation of 'play' $(k r i \bar{l} d \bar{a})$ which also refers to dramatic acting, as in the technical term lāsya, as opposed to tândava—,${ }^{49}$ as well as that of the 'pleasure' derived from playing.

It is this meaning of 'surging forth' - and, implicitly, that of 'playing' (and 'joy of playing', interpreted here as the divine couple's sexual play) — that is Jayaratha's focus, at that stage in his commentary.

In order to gloss sphur, in that context, he uses the root ul-las on two occasionson the second one, in its desiderative form (ullilasișa $)$, which is the source of alliterations evoking the different acceptations of the root: scintillation, play and pleasure:

[...] tatah sphuritabhāvah parānapekșatvena svata evollasitasattāko yo 'sau [...] visargo bahir ullilasișāsvabhāvah [...],

"[...] This "emission" [the creation, brought forth by the divine couple] is "of a radiating nature" (sphuritabhāva), which means that its existence surges forth/manifests itself (ullasitasattāka) spontaneously, in the absence of any desire for something else. [...] This ["procreation" of the phenomenal world] consists in the desire [on the divine dyad's part] to surge forth/to manifest itself (ullilasiṣā) externally.'

\footnotetext{
$\overline{49}$ Note that, according to the Dhätupātha IV 1, 'play' (krī d̦ā) is also one of the acceptations of the root div, 'shine forth', which produces the derivative deva; see also PSV 15, in Bansat-Boudon and Tripathi (2011, p. 127).
} 
Bhavanakartrtā, 'Agency of Being' / 'Quality of Being the Agent of Being'

Utpaladeva seems to have been the initiator of the notion, to be understood as 'agency of being' / 'quality of being the agent of being'. The term occurs, for the first time, in the texts of the Pratyabhijñā, in Utpaladeva's commentary on his own İPK, and in his Vrtti [ŚDvr] on Somānanda's Śivadrșți [ŚD] III 56, with incidentally the same sequence of terms in both cases: sattā, bhavattā, bhavanakartrtāa, presented as quasi-synonyms, and a gloss of sphurattā in the kārikā (see Chart).

Following in the footsteps of his master, Abhinavagupta makes use of the notion in his Vimarśinī on the same passage, İPK I 5, 14 (Chart), and on IPK IV, 6 (Chart), where it is again associated with sattā and sphurattāa. In his ŚDvr III 59, Utpaladeva resorts to another quasi-synonym of bhavanakartrtā, namely bhavanakriyā, the 'act that consists [for him] in being', which sheds light on the core meaning of the term bhavanakartrtā (Chart).

I shall examine in detail what is to be understood by 'agency of being' / 'quality of being the agent of being', and what are the implications of the notion.

Likewise, the Bhāskarī [Bh] ad IPV is quite clear on the meaning of the term. While commenting on IPPV IV 6, in which Abhinavagupta glosses sattā of the kārikā with two equivalents: bhavanakartrtā and sphurattā (in the form of the adjective sphurattārūpa qualifying bhavanakartrtā), Bhāskara explains:

sattā iti padạ̣ vyācașțe bhavana iti / bhavanakartrtā bhūkriyākartrtvam astīti sat tasya bhāvaḥ sattā iti nyāyāt iti bhāvah/,

"He [Abhinavagupta] explains the word "sattā" by "bhavana". 50 Hence "bhavanakartrtā" means "agency of the action of being" (bhükriyākartrtva) by virtue of the rule: "sat" ("being"), meaning "asti" ("he is"); the condition of that ["being"] is sattā; such is the purport.'

In a first stage, a fact stands out incontrovertibly: one has to infer from the comparison between occurrences of the term, as they are collected, for instance, in the comparative chart, that the context in which bhavanakartrtia and its quasisynonyms are used is that of the creation of the phenomenal world by the Lord (particularly, İPvr and İPV II 4, 20, ĪPK II 4, 21, and Vrtti ad loc., ĪPV IV 6, which refers to the viśvapati, and ŚDvr III 56; see Chart). And generally these notions are invoked by the nondualist Śaivas as arguments in the polemic that pits them against the Vedāntins on the question of the śantabrahman (see, particularly, İPK II 4, 20 and the Vrtti and Vimarśin̄ ad loc., as well as ŚD III 55-59 and Vrtti ad loc.; see Chart).

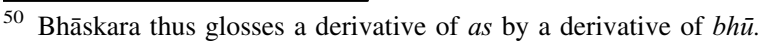




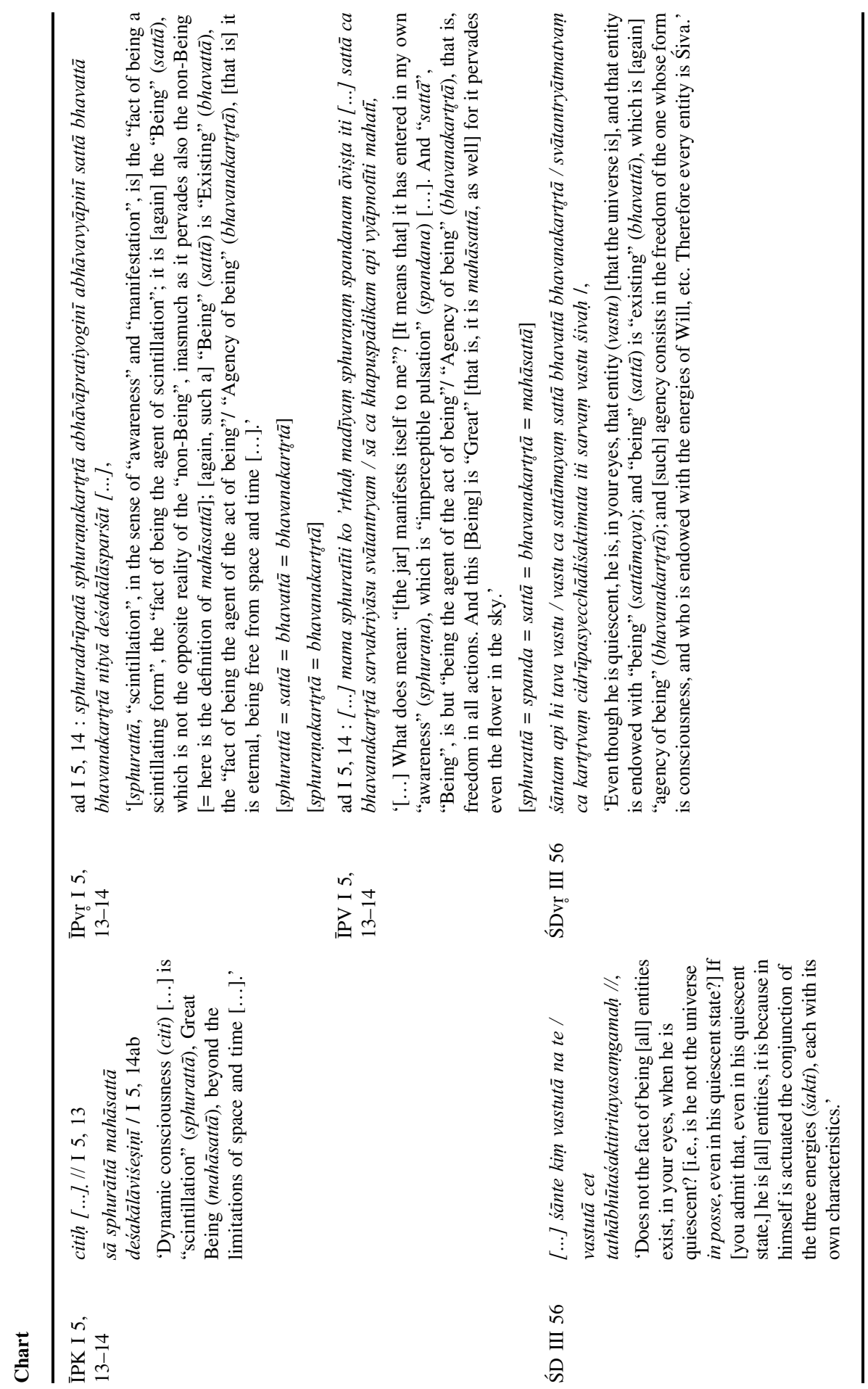




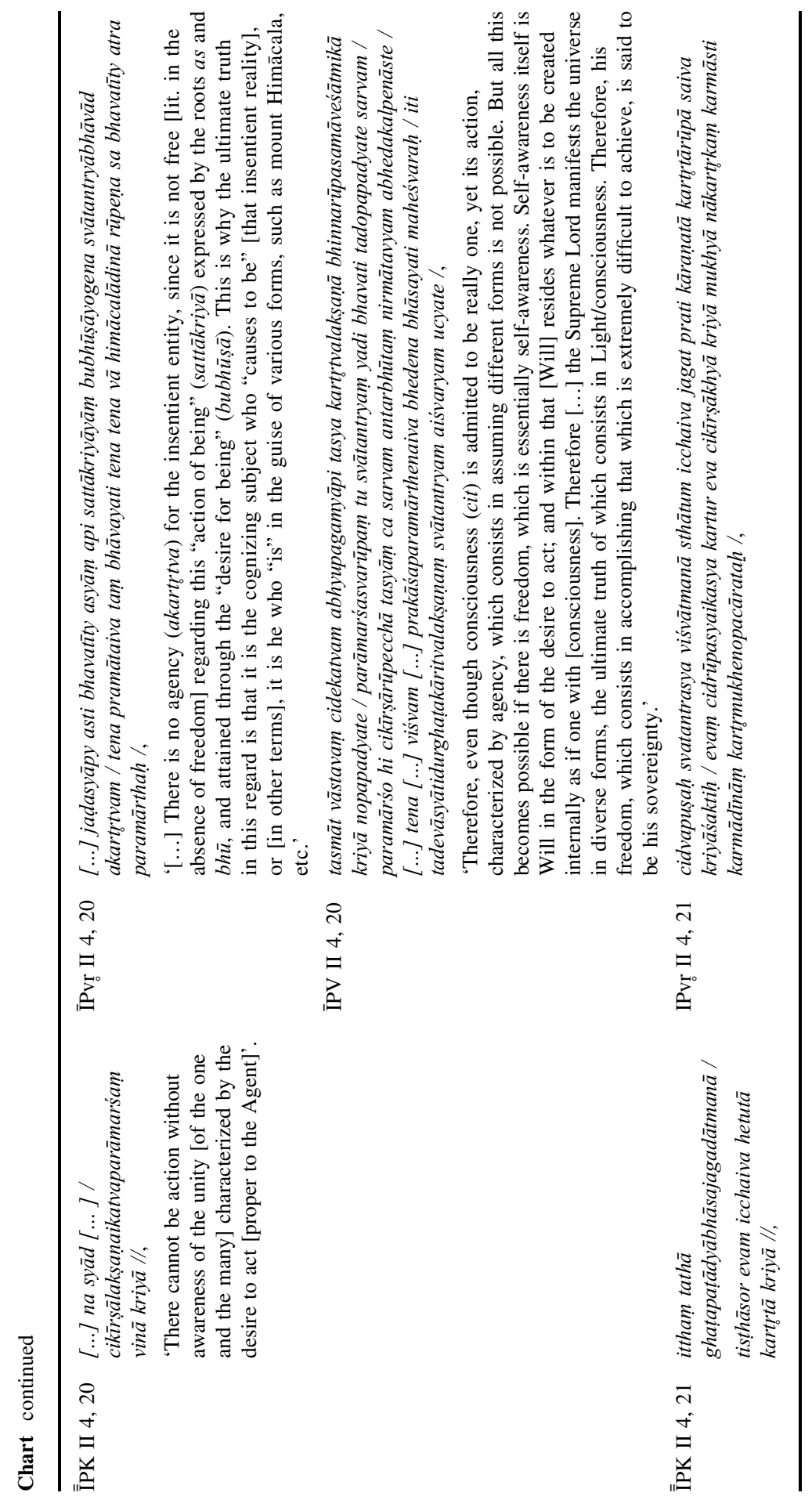




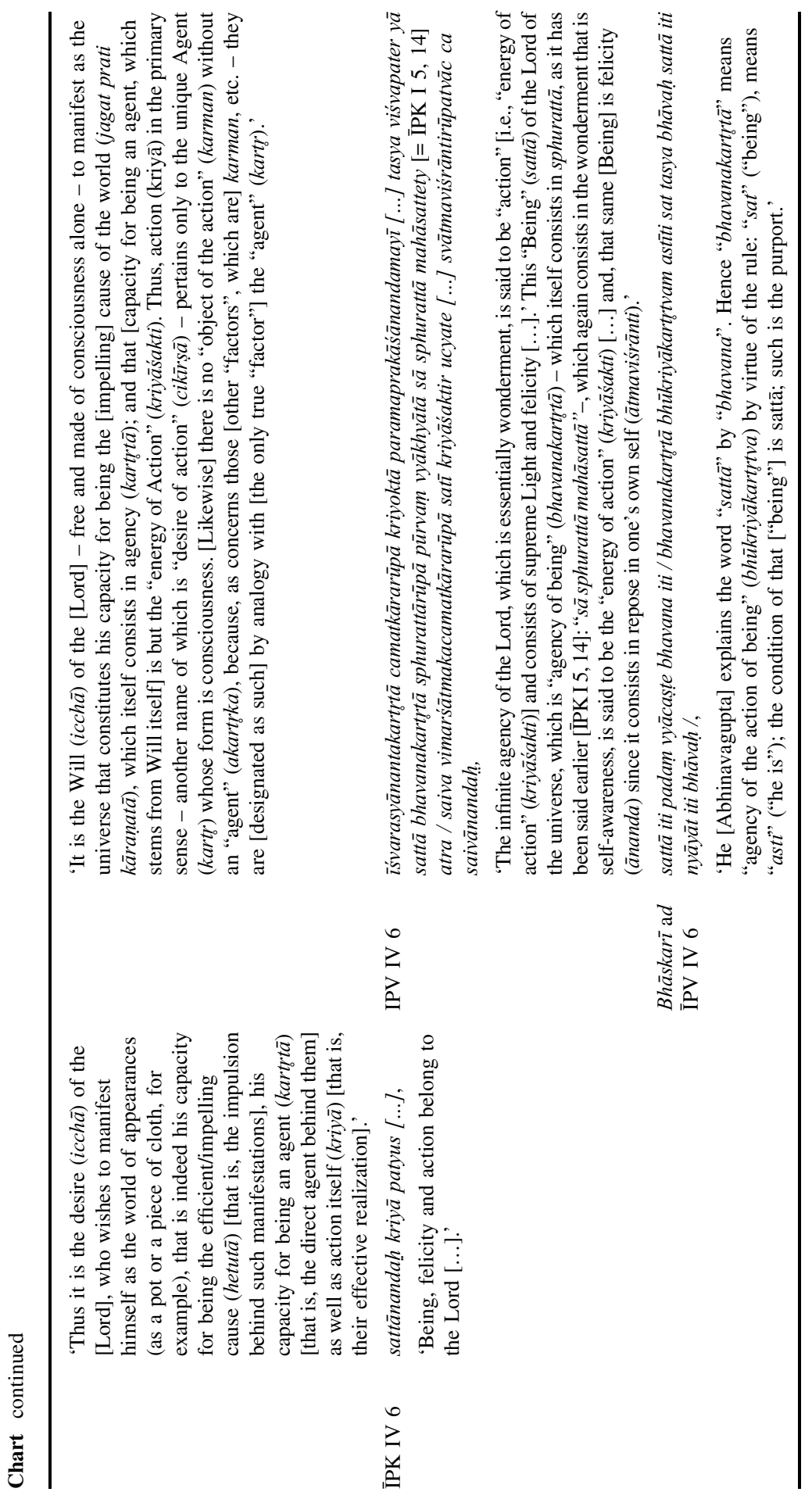




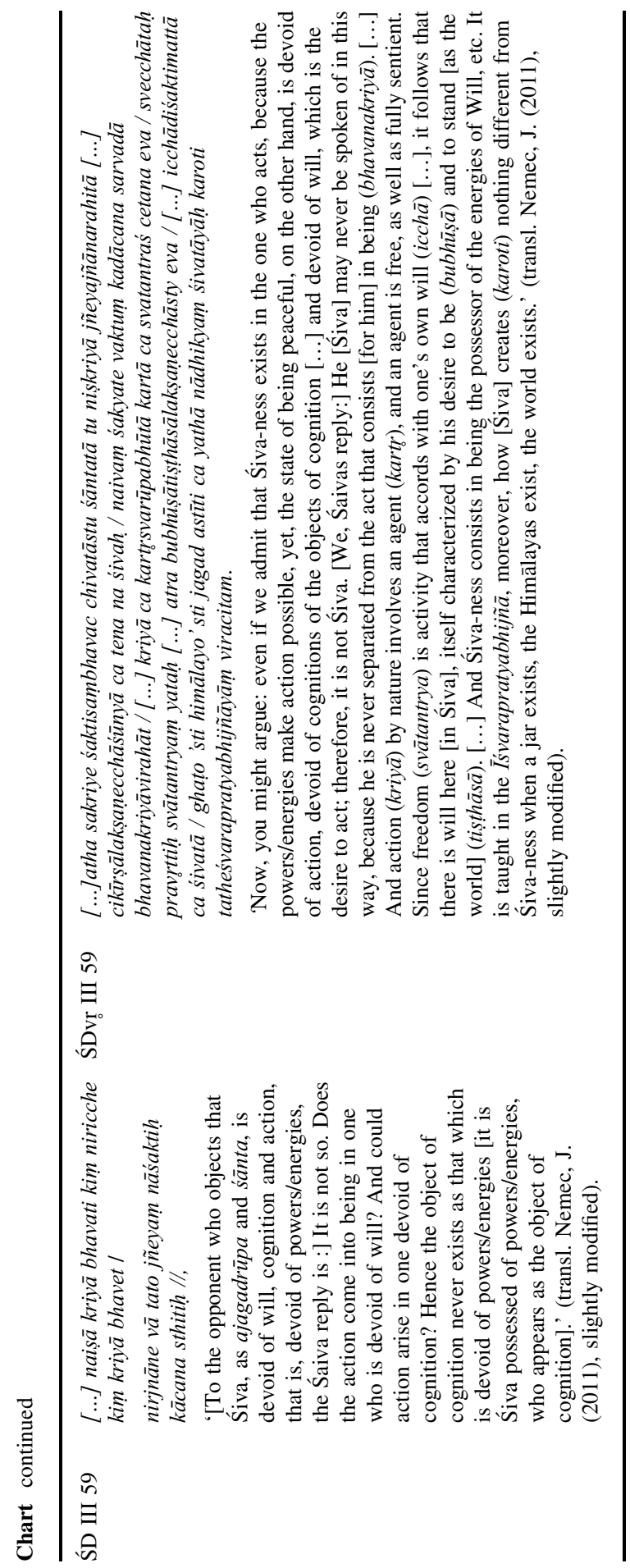


It is not by chance that, in Yogarāja's commentary on the Paramārthasāra, the term occurs first ( $a d 4$ ) in a cosmogonical context, that of the Lord's manifestation in the form of the four andas, '[cosmic] spheres', themselves encompassing an infinite variety of worlds and their inhabitants (see PS 5), and whose main function is to circumscribe and delimit the Lord's infinite subjectivity, or rather 'ipseity' (ahantā), conceived of as his sovereign freedom, the very exercise of which postulates his omnipotent agency $($ kartrt $\bar{a})$ :

[idam aṇdacatuștayaṃ] 'prabhāvitam' prakāśitam bhavanakartṛtayā vā prayuktam / kasmād ity āha 'nijaśaktivaibhavabharāt',

'[This tetrad of andas] "has been brought forth" (prabhāvita), [by the Lord], that is, has been made manifest (prakāśita), or rather made effective (prayukta) by his agency of being/becoming (bhavanakartrtā). How? The master says: "By display of the glorious superabundance of his own energies".'

Described further on as fitted within one another, these four andas represent, not only the whole of Creation, but the progressive constriction of pure, free, ever-radiating consciousness - a process which, resulting in the different grades of experience, could rightly be seen as a 'genesis of bondage', 51 itself likely to be reversed, according to the soteriological aim of the doctrine, and to become a 'genesis of liberation'.

It is but secondarily that those andas pertain to the realm of materiality, insofar as they have for their efficient cause the display of the Lord's energies-in the first place, the display of his energy of freedom, ${ }^{52}$ then of the entire wheel of his innumerable energies - and are therefore of an "energetic" essence (a truth further evidenced by the name of the first of them, saktyanda). ${ }^{53}$ So much so that the commentary concludes:

\section{bhagavatạ̣ kila svaśaktivikāsasphāra eva jagannirmānam,}

'Thus, the confection of the world ${ }^{54}$ is indeed but the sudden bursting into

bloom of the Lord's own energies.'

Here is indeed a strange construct: far from being entirely reducible to the materiality of the world (viśva, sarva) the notion of anda-an innovation, in its Śaiva sense, and whose source, moreover, is the Mālinivijayottaratantra [MVT], the Āgama considered as authoritative for the Trika-contains in itself the

\footnotetext{
51 On this notion, borrowed from Hulin (1978), and the opposite notion of 'genesis of liberation', see Bansat-Boudon and Tripathi (2011, pp. 77, 323-326).

52 See avat. ad PS 4, Bansat-Boudon and Tripathi (2011, pp. 76-77): '[...] it is the supreme freedom of the Supreme Lord alone that constitutes the source of [his] agency, [made manifest in] conjoining and disjoining [his innumerable energies].'

53 Same reasoning in TĀ VIII 171-172, commenting on TĀ VIII 169 (itself a quotation from the Raurava[āgama]): vastupiṇ̣a iti proktam śivaśaktisamūhabhāk / aṇ̣ạ syād iti tadvyaktau sammmkhībhāva ucyate // tathāpi śivamagnānām śaktīnām aṇdatā bhavet / tadartham vākyam aparam tā hi na cyutaśaktitah //, 'Since this anda, which is [essentially] an assemblage of Śiva's energies, has been described as "aggregate of entities" (vastupinda), it is spoken of as their [energies'] objectification (sammukhībhāva), in the process of manifestation. Even so [one may object], the condition of being anda could be predicated of the energies that are immersed in [i.e., that are one with] Śiva. For that reason [i.e., in order to avoid the fault of a too wide definition], another syntagm [qualifying anda, has been given (in VIII 169a), namely, 'pracyutah śaktirūpatah', from which it may be inferred that] those [energies] have not deviated from their nature as energies [viz., being one with Siva].'

54 Same expression in PSV 27, quoted, infra, p. 64: viśvanirmāṇahetuh.
} 
philosophical and theological justification of the existence of a world in an idealistic, therefore monistic, doctrine of pure consciousness; this notion of anda is hence the result of an essentially philosophical effort.

The novelty of the Traika treatment of the notion consists, in the first place, in the utilization of the connotations of the term itself, whose primary meaning, 'egg' or 'envelope', refers to a form which is both impenetrable and constrictive. ${ }^{55}$

On the other hand, the supreme ingenuity is to have conceived no less than a tetrad of andas, furthermore a tetrad structured as a set of forms interlocking within one another, capable of spatially representing the very idea of a progressive and ineluctable constriction of the fluidity and the original universality of the sole reality, consciousness. Thus the four andas are conceived of as increasing constrictions put upon the Lord's absolute pervasiveness and freedom, so much so that the infinite is reduced to the finite. Hence this constriction of an ontological nature, being in essence dynamic - in the image of the supreme principle or Lord, endowed with his śaktis (śaktimant) and animated by them-successively brings into being the finite subject (śaktyanda and māyānda) and the objects of his experience (prakrty- and prthivy-andas).

As such, these andas are not only cosmic spheres, but metaphors for the different grades of experience or subjectivity-whether this experience takes place at the level of pure manifestation, or pure subjectivity, which is that of saktyanda, or at the level of the phenomenal manifestation and embodied subjectivity which māyannda, prakrtyanda and prthivyaṇda account for. ${ }^{56}$

Everything starts with śaktyanda, lit., the 'sphere of Energy'. In fact, Śakti, the very power of the Lord, once transformed by him, out of his absolute freedom, into the power of negating his own essential nature, which is plenitude, gives rise to the other three levels of experience which are, as śaktyanda itself, as many levels of bondage.

Thus, the theory of the four andas is an ontological requirement of the system, and this is the reason why its exposition is placed at the very outset (verses 1-3 being only the "myth of origin" of the text) of the Paramārthasāra. As an epitome of the nondualist Śaiva doctrine, whose main purport is the defence of the jīvanmukti, the Paramārthasāra considers the main problem of empirical being to be that of delimitation, and aims at explaining how diversity takes place so as to enable the reversal of the process and the recognition (pratyabhijña) and re-experience of one's own fundamental plenitude.

This long exposition on the theory of the andas is not a digression. It is essential (as shown by the exposition strategy of the Paramārthasāra) to understand the significance of the concept of bhavanakartrtā, in its relation to the supreme principle on the one hand, and to the materiality of the world, on the other. One of the keys to the comprehension of this is to be found in PSV 4 and 27. Here is the first text, avat. ad PS 4:

\footnotetext{
55 As an 'egg' or an 'envelope', the anda is seen as a form given to the formless, hence as a cover, veiling the pure Light (prakāśa) of the Self/consciousness, and further covering the world that it encompasses. Thus, the other aspect of the definition of anda consists in its being a cover (ācchādaka), a sheath (kośa), as explained by PSV 4.

56 See PS 4 and its detailed commentary in Bansat-Boudon and Tripathi (2011, pp. 76-82).
} 
adhunā [...] viśvavaicitryacitre asmin jagati pārameśvaram anuttamam svātantryam ekam eva samyojanaviyojanakartrtvahetuh iti tacchaktivikāsam eva viśvam andacatuștayamukhena āvedayan grantham avatārayati,

'Now, [...] he [the author, Abhinavagupta] starts the text [proper] by stating that it is the supreme freedom of the Supreme Lord alone that constitutes the source (hetu) [lit., the 'impelling cause'] of his agency (kartrtva) as regards this world [hence, the Lord's freedom is the impelling cause of that world, whether it is created or disolved], marvelous with the diversity of everything in it, [made manifest in] conjoining or disjoining [the host of his energies, bringing about, on the one hand, the dissolution, on the other, the creation of the world] - thus making it known that this world is nothing but the blossoming of his energies through the intermediary of the four [concentric] spheres/envelopes.'

This text is to be compared with PSV 27, which, while examining the conceptions of the Self propounded by the Vijñānavāda and the Śāntabrahmavāda, refutes them both in keeping with the following line of argument:

atrobhayatrāpi vedanasya svātantryam jīvitabhūtam viśvanirmāṇahetuh ${ }^{57}$ iti na cetitam,

'[We, however, reply:] — In both these [doctrines, though the conscious principle has been formulated as supreme], what has not been recognized is the freedom of that conscious principle, ${ }^{58}$ which, endowed with life, becomes the efficient cause (hetu) of the construction of the universe.'

In both passages, emphasis is put on the Lord's (energy of) freedom, (svātantrya [śakti]) considered to be the hetu, the 'efficient (or impelling) cause', of the universe. Moreover, the Lord's freedom is not directly the impelling cause of the world, but that of its 'construction' (nirmāna) or 'making' (kartrtva, siddhi), as also taught in $\mathrm{PH} 1$ :

citih svatantrā viśvasiddhihetuḥ,

'Free consciousness is the cause bringing about the universe.'

Based on the usage of grammarians (P. I 4, 54-55), hetu is the 'causative agent' as contrasted with the 'agent' (kartr) of its embedded base verb.

In the sense that it is one of the realizations of that energy of freedom, kartrtā, the Lord's 'agency' (as it is said in the avat. ad 4, quoted above), or more accurately, bhavanakartrtā, the Lord's 'agency of being' (as specified further on in the same passage) must be understood on two different levels, depending on whether it concerns being the agent of the world or of oneself, as we shall see.

The grammatical logic underlying Śaiva speculations can be read even in the very notion of svattantrya, the prevalent śakti of the Lord, regularly associated to the notion of hetu, which is both 'efficient cause', and, as seen above, 'subject' of the

\footnotetext{
57 See supra, n. 54.

58 See also İPvr II 4, 20 and its criticism of the śāntabrahmavāda: ekasmimiś cittattve 'pi [...] na ca tatra kriyätvam, 'Even if one posits the conscious principle as the only reality [...], there is no action in this conscious principle' (transl. Torella 1994).
} 
causative verb. Indeed, in the grammatical terminology, the term svätantrya refers to the agent's (or grammatical subject's) characteristic 'autonomy'. 59

Thus, the first text (PSV's avat. ad 4, supra, p. 64) refines further the logic underlying Śaiva cosmogony by introducing, between divine freedom, viewed as the pre-eminent efficient cause, and the effects it induces, i.e., the creation, the necessary link in the form of the Lord's capacity for action (kartrtā), which consists in his dual capacity for being and for causing to be that is inherent in the notion of bhavanakartrtā, as will be shown.

By contrast with the quiescent brahman of the Advaita Vedānta, ${ }^{60}$ the Lord, in the Trika, is not only an Agent, but the sole Agent, since sentient beings are nothing but materializations of himself (or, by reference to a recurrent metaphor in the Trika, they are as many theatrical impersonations, bhümikās, ${ }^{61}$ which he chooses to play, in his capacity as Națarāja), and since insentient objects only exist by and through him. Better still, he is agency itself, which is the very expression of his essential freedom. It means that he is the capacity for being all beings, be they sentient or not: not only is he the agent of the world's 'action of being', insofar as he is the one who causes the world to be (the existence of a second "reality" has to be explained somehow in a monistic doctrine), but also he causes himself to be, by being continuously conscious of his being, as expressed by the notions of vimarśa (or spanda, or sphurattā, in some of their acceptations), and supported by the traditional grammatical reasonings which consider that 'to be' is 'to persist in one's own being' (see, infra, p. 72ff.).

In the cosmogonic context of the exposition of the andas (PSV 4, as already examined), the notion of bhavanakartrta implies that the causative underlying the compound has an object, the world, external to the grammatical subject, the Lord. In other contexts, when the exposition remains at the level of transcendence, the underlying causative verb is reflexive: the complement of this "self-effectuation" (he causes himself to be) is the same as the grammatical subject: the Lord brings into being, not the world, but himself, since he is the sole reality. Such is the purport of IPK I 5, 17 (and its $V r t t i),{ }^{62}$ in which the notion of ahammrśyatā, 'self-awareness of the "I"' (or 'I-experience'), conveys the idea of the identity, in the I-experience, of the subject and the object.

That the Lord should cause himself to be is, after all, one of the two necessary correlates of the effervescence (that consists of the sakti-s) constituting the essence of the saktimant, the Possessor of Energies, also seen as the 'Lord of the wheel of energies' (śakticakreśvara); the other correlate of that effervescence being the manifestation of the empirical world.

In this way, 'being' is tantamount to manifesting oneself, in oneself (to oneself) and outside oneself. Thus, manifestation is a mode of being that is subordinated to the desire of being, understood as an "action", whether it is "self-effectuation" or "creation" of the external world-which is nevertheless nothing else than the external

\footnotetext{
59 See Renou (1942), s.v.

60 See PSV 27 quoted infra, n. 66.

61 On this acceptation of bhümikā, see PSV 5, 26, Bansat-Boudon and Tripathi (2011, p. 161, n. 689, 330-331).

62 See Chart.
} 
manifestation of one's own self (bubhūṣā in ĪPvro II 4, 20 = tiṣthāsā in ĪPK II 4, 21 = cikīrșā in İPvr II 4, 21). Such a dynamic process is consubstantial with the supreme principle, the saktimant: he is the effervescent Agent whose vocation is to exceed the limits of his being (hence the concepts of spanda and sphurattā), within the movement of externalization impelled by the triad of the śaktis-icchā, jũāna and kriyā.

As said in a famous verse in the Sarvamangalāśāstra, often quoted in the Pratyabhijñā's texts:

śaktiś ca śaktimāmśs caiva padārthadvayam ucyate /

śaktayo 'sya jagat sarvam śaktimāms tu maheśvarah //,

'Energy and the Possessor of energy[ies] are said to be the [only] two entities.

His energies constitute the entire world, but the Possessor of energies is the Great Lord. ${ }^{63}$

ŚD III 56 (Chart) and ŚD III 59 (Chart), as well as their Vrtti, emphasize that the śaktimattā of Siva is the doctrinal point that solves the aporia of the śantabrahmavāda, although Somānanda and his commentator provisionally accept a distinction between a 'quiescent' (śānta) Śiva (when he is conceived of as the supreme principle, namely, as ajagadrūpa) and a 'gross' (sthūla) Śiva (when he assumes the form of the external world: jagadrūpa) in order to refute their adversaries. ${ }^{64}$ Moreover, Utpaladeva (ŚDvr III 56 and 59) makes the notion of bhavanakartrt $\bar{a}$ - ${ }^{65}$-wich, as already observed, he has "invented" - an irrefutable argument against the Advaitin notion of a śäntabrahman. Possessor of the three śaktis (icchādiśaktimattā ca śivatā in ŚDvr III 59), Śiva is continuously involved in the essential 'act that consists [for him] in being' (bhavanakriyā)—being in oneself (to oneself) and being as the world.

This is what ŚDvr III 59 teaches:

[...] atha sakriye śaktisambhavāc chivatāstu śāntatā tu niṣkriyā jñeyajñānarahitā [...] cikīrșālakṣaṇecchāśūnyā ca tena na śivah / naivam śakyate vaktum kadācana sarvadā bhavanakriyāvirahāt / [...] kriyā ca kartrsvarūpabhūtā kartā ca svatantraś cetana eva / svecchātah pravrttih svātantryam yatah [...] atra bubhūṣātiș̣thāsālakșanecchāsty eva / [...] icchādiśaktimattā ca śivatā $[\ldots]$,

\footnotetext{
${ }^{63}$ PSV 4 quotes it; see Bansat-Boudon and Tripathi (2011, p. 79, n. 311). It is implicitly present in PSV 47-50; see Bansat-Boudon and Tripathi (2011, p. 212, n. 954).

${ }^{64}$ Such is the purport of the long discussion that takes place in ŚD III 53-59 and its Vrtti. The Śaivas transitorily accept the position of their opponents, namely that there is a śanta Siva, when he is ajagadrüpa, 'not in the form of the world', and a sthūla Siva, when he is jagadrūpa, 'in the form of the world' (on this intricate discussion, see Nemec (2011), ad loc.); nevertheless, it is to better refute such an erroneous opinion and re-establish the ontological unity of the Supreme Lord: Śiva is śanta and sthüla indifferently, and at his will, assuming both the conditions as would an actor with his roles, without ever swerving from his very nature. Thus the provisional distinction between the two conditions is a matter of mere convention; see ŚD I 41 cd-43, where Somānanda and Utpaladeva describe Śiva as 'as if' peaceful: svaśivatvam ivājānan paśvātmavyapadeśatah // tadrūpatvena vā paśyan sthitah śānta iva kvacit /, "As if ignoring his own Śiva-nature, he exists as one who is designated a bound soul, or, seing himself as having that nature, he sometimes exists as if he were peaceful.' All translations from ŚD are those of Nemec (2011), sometimes modified.
}

65 And its synonym, bhavanakriyā, in ŚDvṛ III 59. 
'[...] Now, you might argue: even if we admit that Śiva-ness exists in the one who acts, because the powers/energies make action possible, yet, the state of being peaceful, on the other hand, is devoid of action, devoid of cognitions of the objects of cognition [...] and devoid of will, the desire to act; therefore, it is not Śiva. [We, Śaivas reply :] He [Śiva] may never be spoken of in this way, because he is never separated from the act that consists [for him] in being (bhavanakriya $\bar{a}$. [...] And action by nature involves an agent, and an agent is free, as well as fully sentient. Since freedom is activity that accords with one's own will [...], it follows that there is will here [in Siva], itself characterized by his desire to be (bubhūṣā) and to stand [as the world] (tișthāsā). [...] And Śivaness consists in being the possessor of the energies of Will, etc.,'

as well as ŚDvro III 56:

[...] sattā bhavattā bhāvanakartrtāa / svātantryātmatvam ca kartrtvam cidrūpasyecchādiśaktimata [...],

"[...] "being" is "existing", which is [again] "agency of being"; and [such] agency consists in the freedom of the one whose form is consciousness, and who is endowed with the energies of Will, etc.'

Again, in this context, like the return of the subject in the fugue's tonic key, the motive of the Lord's essential freedom reappears, this time associated with the two notions of śaktimattā and bhavanakartrtā. As an omnipotent (śaktimant) Agent (an Agent of his own being as well as the others' being-bhavattā, bhavanakartrtā), the Lord is free. $^{66}$

In conclusion, one should interpret the concept of bhavanakartrtā as the nominal transposition of the causative bhâvayati (with the underlying presence of the embedded base verb bhavati). Such an analysis implies, in its turn, the Traika reasonings on sentience and insentience-a crucial issue in a nondualist system, and which is again related to the major concept of mahāsattā, as will be developed further on, while commenting on IPK I 5, 14ab and its commentaries. ${ }^{67}$

This is the purport of IPvr II 4, 20: ${ }^{68}$

\section{[...] jaḍasya [...] tena pramātaiva tạ̣ bhāvayati tena tena vā himācalādinā rūpeña sa bhavatīty atra paramārthah,}

\footnotetext{
66 In the same way, PSV 27 makes the freedom of the Lord the criterium that distinguishes the Trika from those other nondualisms that are the Vijñānavāda and the Advaita Vedānta: atrobhayatrāpi vedanasya svātantryam jūvitabhūtam viśvanirmānaheturiti na cetitam, '[We, however, reply:]-In both these [doctrines, though the conscious principle has been formulated as supreme], what has not been recognized is the freedom of that conscious principle, which, endowed with life, becomes the efficient cause of the construction of the universe.'

67 See infra, p. 71 and n. 81-82.

68 See the beginning of this text, infra, p. 69 and Chart.
} 
'This is why the ultimate truth in this regard is that it is the cognizing subject who 'causes to be' [that insentient reality], or [in other terms], it is he who 'is' in the guise of various forms, such as mount Himācala, etc.' 69

In this manner it is demonstrated that insentient objects do not exist, at least not really, or not absolutely. The text above offers two possible formulations of the same idea: i) it is the Subject who exists as the object (bhavati + instrumental); ii) it is the Subject who causes the object to exist (bhävayati).

The existence of the sentient and the insentient implies an agent of this existence, his own and that of the insentient entities. Therefore existence implies, not only agency, but causative agency (whether self-referential or not).

The simple verb bhavati is embedded grammatically in the causative bhâvayati, as shown by grammatical terminology which designates the subject of bhavati as 'kartr', and that of bhâvayati as 'hetu' - as the Lord assumes these two modes of the grammatical subject. Thus İPvr II 4, 18 observes:

parịnāme svatantrasya śaktimatah kartrtaiva hetutā,

'For him, endowed with śakti, who is free to modify himself, to be a cause [of the phenomenal world] is to be an agent. ${ }^{70}$

For Siva, the simple bhavati only makes sense with reference to the causative: Siva does not confine himself to being; he causes himself to be as much as he causes the universe to be, failing which he would be the quiescent Absolute of the Vedānta, whereas the phenomenal world would only be explicable by the illusory constructions of a $m \bar{a} y \bar{a}$ conceived of as distinct from the supreme principle, which is nonetheless the sole reality - a $m \bar{a} y \bar{a}$ that is real and non-real, and, in a way, inexplicable (sadasadanirvacanīyā), according to the Vedānta.

From the immanent point of view, bhavanakartrtā thus expresses the paradox of an Absolute (Paramaśiva, pure Being, perfect plenitude) which coexists with its own creation, necessarily external to it-rather, every moment internal as much as external to it. ${ }^{71}$

As SpN I 2 explains:

etad uktam bhavati na prasevakād ivākș̣oṭāi tat tasmān nirgatam api,

'Such is the meaning: that [world of phenomena] has not come out of him [the

Lord] as does a walnut, or anything else, from a bag.'

\footnotetext{
69 Same image in ŚDvr III 59, where Utpaladeva refers to his own İPK; see Nemec (2011, pp. 250, 378): ghațo 'sti himālayo 'sti jagad astīti ca yathā nādhikyam śivatāyāh karoti tatheśvarapratyabhijñāyām viracitam, 'It is taught in the Íśvarapratyabhijñā, moreover, how [Śiva] creates nothing different from Śiva-nature when a pot exists, the Himālayas exist, the world exists.' See also Ratié (2011, pp. 684-685), as well as her references to IPPVV II 4, 20 (n. 93, 94, 95), which evokes a discussion on the $1^{\text {st }}$ verse of the Kumārasambhava, where Himālaya is the subject of 'asti' (asty uttarasyām diśi devātmā himālayo nāma nagādhirāja iti).

70 Here one must note the use of this 'parināma', a paradox in a doctrine that invents the notion of spanda, changeless motion, in order to avoid the suspicion of perishability affected to the Absolute. Therefore, 'parināma' is here divested of its realistic connotations.

71 See IIPV II 4, 20 (Chart): [...] paramārśo hi cikīrșārūpecchā tasyām ca sarvam antarbhūtam nirmātavyam abhedakalpenāste /, '[...] Self-awareness itself is will (icchā) in the form of the desire to act (cikīsșā); and within that [will] resides whatever is to be created internally as if one with [consciousness].'
} 
In effect, bhavanakartrtā designates the Lord's faculty of exerting his power of being - that is, of manifesting himself as the universe, eternally and permanently present in him. Being free, Parameśvara decides to embody reality, in other words, to become "real".

Siva is thus the subject of all the occurrences of the verb 'to be', as taught by IPV I 5, 14:

\section{[...] sattā ca bhavanakartrtā sarvakriyāsu svātantryam,}

"[...] and that "being" is "agency of being", that is freedom in all the actions [of being]. ${ }^{, 72}$

So much so that bhavanakartrtā is to be understood from both points of view: that of Being as such and that of its "real" manifestation-in other words, that of the principle and that of its productions, whatever their degree of "reality".

The Agent's freedom is indeed the cornerstone of these disquisitions: it is the absolute sovereign freedom to act, i.e., to be and bring into being, which inanimate entities lack in order to be "agents", that is to say "subjects" of the verb 'to be'. The passage of İPvr II 4, 20 immediately preceding the one I quote on p. 67, is explicit in this respect:

jaḍasyāpy asti bhavatīty asyām api sattākriyāyām bubhūṣāyogena svātantryābhāvād akartrtvam / tena [...],

'[...] There is no agency (akartrtva) for the insentient entity, since it is not free

[lit. "in the absence of freedom'] as regards this "action of being" (sattākriyā)

expressed by the roots $a s$ and $b h \bar{u}$, and attained through the "desire for being"

(bubhūṣā).'

It is also this freedom that simultaneously controls the desire to be (bubhusșa $)$ and the desire to act (cikirșa ), both of which, in this dynamic ontology, are merged and cannot be conceived one without the other, as shown by the way the Vrtti glosses the cikīsșā of the kārikā by bubhūṣā (see Chart).

Thus, freedom, agency and sovereignty are equivalent, as the IPV II 4, 20 explicitly says:

iti tad evāsyātidurghațakāritvalakṣaṇam svātantryam aiśvaryam ucyate /,

'Therefore, his freedom, which consists in accomplishing that which is extremely difficult to achieve, is said to be his sovereignty. ${ }^{73}$

İPK II 4, 21 and its Vrtti pursue the same line of thought, associating through contiguity the Lord's will (or energy of Will: icchā [śakti]) that governs the desire to be or to manifest (to be read in 'tișthāsu'), his capacity of being the agent (hetuta $=$ kartrtā) of the "real" world, and his effective action $(k r i y \bar{a})$ :

\footnotetext{
72 If one understands: 'freedom in all the actions [of being]', this implies the 'existence' of sentient objects; if one does not supply 'of being', one must understand 'all the actions (including the action of being)'. Complete text of the kārikā supra, p. 54.

73 See complete text, in the chart. Same phraseology in PS 15 (paramam yat svātantryam durghațasampāāanam maheśasya / devī māyāśaktih svātmāvaranam śivasyaitat //, 'The supreme freedom of the Great Lord, which accomplishes what is difficult to construe, is indeed nothing but the covering of Śiva's own Self [in which phase he appears as] the Goddess Māyāsakti.') and PSV ad loc.
} 


\section{ittham tathā ghațapațādyābhāsajagadātmanā /}

tișthāsor evam icchaiva hetutā kartrtā kriyā // (ĪPK II 4, 21),

'Thus it is the desire (icchā) of the [Lord], who wishes to manifest himself (tișthāsu) as the world of appearances (as a pot or a piece of cloth, for example), that is indeed his capacity for being the efficient/impelling cause (hetutā) [i.e., the impulsion behind such manifestations], his capacity for being an agent (kartrtā) [i.e., the direct agent behind them] as well as action itself $($ kriy $\bar{a})$ [that is, their effective realization]. ${ }^{74}$

Therefore the series of equivalences, in the kārikāa, is the following: icch $\bar{a}=$ hetut $\bar{a}=$ kartrta $=$ kriya $\overline{\text {. }}$

İPvr II 4, 21 insists on these two notions of causative agency and agency (kāranata $\left[=\text { hetut }^{2}\right]^{75}$ and kartrtā $)$, where one can discern the underlying presence of the notion of bhavanakartrtā, interpreted here as inseparable from the very idea of cosmogony, and associated with the notion of kriyāsakti, 'energy of Action', itself resulting from icchā [śakti], 'energy of Will':

cidvapuṣaḥ svatantrasya viśvātmanā sthātum icchaiva jagat prati kāraṇatā kartrtārūpā saiva kriyāśaktih / [...],

'It is the Will (icchā) of the [Lord] - free and made of consciousness aloneto manifest as the universe that constitutes his capacity for being the [impelling] cause of the world (jagat prati kāranatā) — a capacity that itself consists in agency; and that [capacity for being an agent, which stems from Will itself] is but the "energy of Action".'

Here, the series of equivalences is as follows: jagat prati kāranatā $=$ kartrtā $=$ kriyāśakti =icchā [śakti] — the same, therefore, as in the kārikā (ĪPK II 4, 21); see Chart.

As he completes the process of establishing the Lord as the sole Agent, willing to manifest himself as the "other", Utpaladeva, in his gloss ad II 4, 21, transposes the philosophical argument (expressed in the first part of the sentence: nākartrkam karmāsti karmādīnām kartrmukhenopacāratah) to the grammatical register:

evam cidrūpasyaikasya kartur eva cikīrșākhyā kriyā mukhyā nākartrkam karmāsti karmādīnām kartrmukhenopacāratah /,

'Thus, action $(k r i y \bar{a})$ in the primary sense-another name of which is "desire of action" (cikirșā)-pertains only to the unique Agent whose form is consciousness. [Likewise] there is no "object of the action" (karman) without an "agent" (kartr), because, as concerns those [other "factors" (kārakas), which are] karman, etc.- they are [designated as such] by analogy with [the only true "factor"] the "agent" (kartr).,76

\footnotetext{
74 Or: 'Thus it is the desire (icchā) of the [Lord], who wishes to manifest himself as the world of appearances (as a pot or a piece of cloth, for example), that is indeed the indirect cause (or impulsion) [behind such manifestations], as well as their efficient cause, and their effective realization.'

75 The word kāranatā, derivative of the causative verbal form, is equivalent to hetutā.

76 Lit.: "because of a metaphorical usage, made possible through the agent, of karman, etc., [i.e., of the term 'käraka', 'factor', applied to factors that are other than the agent]". In other words, in the case of the term 'kartr', there is no metaphor; in the case of the other 'semantic roles', there is a metaphor, since they
} 
Indeed, the passage is difficult to understand, ${ }^{77}$ nevertheless the interpretation that I propose seems justified to me, mainly, by the $-\bar{a} d i$ element in karmādinām, which indicates the beginning of a list: my view is that karman is here to be understood as one of the kärakas, 'factors'-excluding kartr, obviously, since in Utpalaveda's sentence the kartro is left out of the list of the kārakas.

Pāninian grammar starts with kārakas, which are structured around a kriya - the 'action', or process, expressed by the verb. As a result, the kārakas are 'semantic roles', or 'actants', to borrow from generative semantics, in other words they are all participants in the process expressed by the verb, all roles played around this process. ${ }^{78}$ Not only is the agent one of these actants, but it is first among them, playing the leading role and creating the roles around it, which only exist through it. It is the agent who/which knows that other "actants" exist and causes them to be, as it causes the action to be. ${ }^{79}$

Without an agent, there would be no other kārakas. Likewise, in the philosophical argument in debate in the Vrtti, it is the Agent alone who exists, because he causes all other entities to exist. The grammatical argument is equally valid as an example pertaining to analogy: what holds true for the grammatical agent also does for the supreme Agent.

And-taking even further the virtuosity of this idealistic system, which contrives to resolve the logical impasses that made the rival doctrines stumble, be they monistic or dualistic - the texts add that this 'being' (sattāa), which involves the 'action of being' (sattākriyā) and 'the action of causing to be' (bhavanakartrtāa) ${ }^{80}$ in other terms, this 'beingness' which involves 'agency' (and 'causative agency') _ brings into being, not only the insentient objects with a proven existence, but also imaginary insentient objects, such as the 'flower in the sky' (see İPV I 5, 14, infra). This is why, borrowing the concept, in particular, from the philosophy of grammar, ${ }^{81}$ IPK I 5, 14 teaches that this 'being' is also said to be a 'Great being' (mahāsattā); he is "great" insofar as he penetrates all reality, existent and non-

Footnote 76 continued

are not 'factors' ( $k \bar{a} r a k a)$, strictly speaking: it is the agent who is the only 'factor', the one which causes action, as well as the other semantic roles, to be.

77 Torella (1994, p. 188) seems to adopt the same interpretation (see his n. 37), but his translation does not entirely account for the grammatical implication of the sentence.

78 On these notions, see Kiparsky (1993, p. 2922): 'A sentence is seen as a little drama played out by an Agent and a set of other actors, which may include Goal, Recipient, Instrument, Location and Source. These roles are systematically related to semantic categories, but the correspondence is not one-to-one. One käraka can correspond to several semantic relations and one semantic relation can correspond to several kärakas, in ways duly stated in grammar.'

79 Thus kārakas cannot be mistaken for the syntactic functions expressed by grammatical cases; rather, as stated by Kiparsky (ibid.): 'Kärakas in turn are the categories in terms of which the assignment of case and other morphological elements is formulated.' For example, the notion of 'subject' is pointless in the Indian context; what matters is the notion of 'agent', which occurs under two different forms: as the nominative, in the active; as the instrumental, in the passive. Symmetrically, the 'object' occurs as the accusative, in the active; as the nominative, in the passive.

${ }^{80}$ Cf. İPvr II 4, 20, quoted supra.

81 On the notion of mahāsattā, see, notably, Bansat-Boudon and Tripathi (2011, p. 206 (n. 915)), and 339. IPV I 5, 14 glosses again mahāsattā as mahādevi, through the citation (vol. 1: 261): mahāsattā mahādevī viśvajīvanam ucyate. 
existent. ${ }^{82}$ Such is the exercise of the Lord's sovereign liberty, as he is citi, dynamic consciousness.

This is how one can perceive coming through the logic underlying the juxtaposition of notions presented as quasi-synonyms in IPK I 5, 14 and in its commentaries (see Chart).

Thus are justified, i) on the one hand, the series of equivalences proposed by İPK I 5, 14: sā [citih]] sphurattā mahāsattā [...], in which mahāsattā glosses sphurattā (itself understood, as the Vrtti observes, as sattā, bhavattā and bhavanakartrtā), which itself glosses the term citi in I 5, 13 whose predicate it is; ii) on the other hand, 1. the parallel series of glosses proposed for sphurattā by İPvr ad loc.: sattā bhavattā bhavanakartrtā (see Chart); 2. another series proposed by İPV ad loc.: [...] sattā ca bhavanakartrtā sarvakriyāsu svātantryam / sā ca khapuṣpādikam api vyāpnotīti mahati /, whose last segment (sā ca khapuṣpādikam...) is a gloss to a 'mahāsattā' unexpressed in the Vimarśinī itself.

This logic, which refers to the notions of 'being', 'great being', 'action of being', 'subject-agent of the action of being', proceeds through channels and reasonings which are those of grammar, at any rate, of orthodox grammatical tradition, in other words that of Brahmanism (as opposed to the Buddhist tradition, which rejects any idea of a Subject which would be a permanent, active Self), for which, even though the verb is theoretically understood as an action, ' $k r i y \bar{a}$ ', stative verbs like $a s, b h \bar{u}$, and a few others equally correspond to this idea of "verbality" as being "agency": 'being' is 'action of being'. 83

Examining some of the reasonings elaborated in the texts, one can construe that that there was some debate about the question of the "verbality" of the roots conveying the meaning of "existence". Taking up the Mīmāmsaka analysis of the verb, which introduces the notions of vyāpāra and phala, Nāgeśa, in his PLM (in the Dhätvartha section, according to the commentator's segmentation of the text: atha dhātvarthanirūpanam), teaches (p. 98):

astibhavativartatividyatīnām arthaḥ sattā / sā cānekakālasthāyinīti kālagatapaurvāparyeña kramavatīti tasyāh kriyātvam / satteha ātmadhārañam,

'The roots $a s, b h \bar{u}, v r t$, and vid signify "to be" (sattā). That [sattā] is present in several tenses; therefore, since that $[s a t t \bar{a}]$ involves temporal continuity, it is

\footnotetext{
82 On this point, a distinction must be made, it seems to me, between objects which are imaginary, but could nonetheless exist (were it only in the mind of a poet) and standard examples of logical impossibility (such as a 'barren woman's son'); I must differ on this point from Ratié (2011, p. 687 (n. 101)). Even imaginary constructs are part and parcel of the Lord's phenomenalizing power: the city up above in the air, the flower in the sky, the hare's horn do not refer to a logical impossibility like the notions of 'a square circle' or a 'barren woman's son'. Undeniably, the latter cases can be constructed mentally as contradictory beings, but they cannot "exist"; as postulated by Leibnitz, they are not 'compossible', in that they represent two incompatible possibilities-which is not the case for the 'hare's horn', which happens not have materialized, but which nothing would prevent from materializing. For that matter, these imaginary constructs are the privilege of poets, as stated by Bhatta Tauta, one of Abhinavagupta's masters: 'The earth with the mountains for teeth, or the sky adorned with the halo of lightning, [what does it matter] that such things do exist or not! For might it not be possible that they do some day, somewhere?' (Abhinavabhāratī ad Nātyaśāstra XIX 129, quoted in Bansat-Boudon (1992, pp. 155-156).

83 See supra, p. 48 , n. 26.
} 
durative [i.e., it is a durative activity]. Therefore, it expresses an action (kriyātva). For "to be" (sattā) here consists in persistence in the Self., ${ }^{84}$

The argument here is that of persisting in being; the activity referred to by the verb 'to be' implies an action, an effort: that of persisting; what is in question is persistence rather than existence.

It is in such a context that the modern commentary of Kalikaprasad Shukla leads us to discern the implicit objection to which PLM's passage quoted above is an answer:

nanv evam astyādīnām dhātutvānāpattis teșām sattāmātrārthatvena vyāpārarūpakriyāvācakatvābhāvāt ata āha [...],

'But, if it so, how could as, etc., be roots, insofar as they do not express activity (kriyā) which consists in "operation" (vyāpāra), ${ }^{85}$ since they only signify "to be" (sattā)? Therefore, he says [...]'.

Trika speculations remove this suspicion, in their own way, in agreement with the dynamic ontology that characterizes them. ${ }^{86}$ On this point, Śaivas, in the persons of Utpaladeva and Abhinavagupta, stick to Pāninian reasonings: whether they are stative or action verbs, all verbs are actions, since they are given "personal" endings denoting the existence of an agent of that action, albeit the 'action of being'. Such is the meaning of Utpaladeva's statement, in his ŚDvr III 57-59:

bhavatītyādi tinantanirdeśạ,

'[Pāṇini] teaches that verbs like bhavati "to be, to become" end with a verbal ending., 87

As stated in the Dhâtupātha: bhū sattāyām, 'bhü means "to be", , and one would not be allowed to see there, as the Mīmāmssaka analysis would have it, either phala, or vyāpāra. Likewise P. I 3, 1 defines verbs (roots) as those 'beginning with $b h \bar{u}$ ': bhvādayo dhätavah.

To the equation which postulates that 'being' is 'action of being', IPK IV 6 adds a third term: ānanda, 'felicity':

sattānandaḥ kriyā patyus,

'Being, felicity and activity belong to the Lord.'

It is in the context of defining the 'Lord of the universe' — viśvapati, as said in the IPV ad loc. (see Chart)— that the triad sattā-ānanda-kriyā occurs. If compared to another triad, that of the Advaita, sat-cit-ānanda, 'being, consciousness, felicity',

\footnotetext{
84 Transl. Kunjunni Raja, slightly modified, in Coward and Kunjunni Raja (2001, p. 331).

85 The activity expressed by the verb (kriyā) is analysed in two parts: vyāpāra (itself associated with yatna, 'effort') and phala, the 'aim' of this activity; see supra, n. 26.

${ }^{86}$ See the use of the root sthā, in the desiderative, in İPK II 4, 21, and Vimarśinī ad loc. Tișthāsā, the 'desire to be (or to manifest)', tișthāsu, the 'one who desires to be', viśvātmanā, 'in the form of the world', function as synonyms of the derivatives from $b h \bar{u}$. This is how, incidentally, I differ in my translation of ŚDvr III 59 (see Chart) from Nemec's interpretation of tișthāsā (2011, p. 249): 'his desire to remain in existence'.

87 Transl. Nemec (2011, p. 249).
} 
one notices that kriyā of the Śaiva list in some way takes the place of cit, conceived as śānta, in the Advaitin enumeration. Thus, kriya involves the dynamic dimension that the Śaiva system confers to consciousness. Moreover, the context is different, since the triple qualification, sat-cit-ānanda, applies to brahman (the non-supreme brahman, at least), conceived of as śānta, whereas the triad sattā-ānanda-kriyā qualifies the supreme principle, which is considered as the 'Lord of the universe', viśvapati, the one whom İPK II 21 describes as 'desirous of manifesting himself in the form of the world', that is, desirous of immanence and, as such, conceived of as the supreme Agent.

And, even more, if the term ananda is common to both lists, a subtle shift concerning the object of this felicity can be observed: in the Śaiva system, one delights in, not only 'being' (sat), or 'being consciousness' (sat, cit), for all eternity, like the aparabrahman of the Advaitins, but also in being the agent of one's and the others' being - so to speak, in being the universe in posse before being that in esse. This distinction however makes no sense as concerns ultimate reality (paramārthatah); it is a conventional distinction, characteristic of ordinary speech, that of the world of transmigration. ${ }^{88}$

Furthermore, in the Trika, the analogy of felicity (or bliss) is extended far beyond the usage found in the Advaita: this felicity is also camatkāra, 'wonderment', as well as ätmaviśrānti, 'repose in the Self' ${ }^{89}$-notions that Śaiva metaphysics shares with Śaiva aesthetics. ${ }^{90}$ This is what states İPvr IV 6:

\section{iśvarasyānantakartrtā camatkārarūpā kriyoktā paramaprakāśānandamaȳ̄ $[\ldots]$,}

'The infinite agency of the Lord, which is essentially wonderment, is said to be "action" [i.e., "energy of action" (kriyāśakti)] and consists of supreme Light and felicity $[\ldots]$,'

and the Vimarsinin ad loc.:

tasya viśvapater yā sattā bhavanakartrtā sphurattārūpā pūrvam vyākhyātā sā sphurattā mahāsattety [= İPK I 5, 14] atra / saiva vimarśātmakacamatkārarūpā satī kriyāśaktir ucyate [...] svātmaviśrāntirūpatvāe ca saivānandah,

"This "Being" (sattā) of the Lord of the universe, which is "agency of being" —which itself consists in sphurattā, as it has been said earlier [ĪPK I 5, 14]: "sā sphurattā mahāsattā"-, which again consists in the wonderment that is self-awareness, is said to be the "energy of action" (kriyāśakti) [...] and, that same [Being] is felicity since it consists in repose in one's own self.'

\footnotetext{
${ }^{88}$ Cf. notably-III 47cd (and Vrtti): samjjūākaraṇamātram tad vyavahārāya kalpitam //.

89 This refers to the recurrent notion of ahantācamatkāra, the 'marvel of supreme ipseity'. See, e.g., PSV 2-3, which explains the name 'Abhinavagupta' as the 'one who is hidden (gupta), i.e., who is himself a secret, i.e., who is possessed of secret [wisdom] due to his experiencing the ever new (abhinava), supramundane (alaukika), sudden burst (sphāra) of the state of wonder (camatkāra) that is consciousness: [...] gurur abhinavena alaukikena ciccamatkārasphāreṇa guptah guhyah sarahasya iti. See also PSV 79-80.

90 See Bansat-Boudon and Tripathi (2011, pp. 55-56).
} 
And through this felicity associated with agency, one is led back to the notion of sovereign freedom, for this freedom of the Lord, as taught by PSV 10-11, is to be distinguished from that of 'insentient objects such as crystal-gems, mirrors, etc'. On the contrary, as stated further on by PSV on the same verse:

svātmani viśrāntito mahānandam iti / svasminsvabhāve 'khaṇạahantācamatkārarase viśramān mahānānandah parā nirvrtir yasyeti /,

'[The Lord" is] "supremely blissful (mahānanda), on account of "reposing in itself", that is, he is endowed with great bliss, with supreme felicity, due to the fact that it reposes in his own true nature, [informed by] the delight (rasa) that arises from the state of unfragmented wonder that is [supreme] ipseity (akhaṇ̣̂āhantācamatkāra).'

Interpreted thus, the agency of being appears as the necessary correlate of a theistic system, in which the supreme principle is the Lord (iśvara or pati, as in IPK IV 6) — the Lord's sovereignty being thus indistinct from his freedom.

If it is so, one might object, why maintain the notion of $m \bar{a} y \bar{a}$, in Trika philosophy, insofar as a divine Agent suffices to cause the world to be? Answering this question here would be overlong. On the other hand, the answer to the question: 'Why is it that the Trika maintains the notion of māya ?' would doubtless be that, in the Trika, $m \bar{a} y \bar{a}$ has come to be a sakti of the Lord (it is noteworthy that, in the process of enumerating the thirty-six tattvas, PS deals with māyāśakti in v. 15), more exactly a hypostasis of Śakti, with which he constitutes an indissoluble dyad, one of whose names is svattantryaśakti. This is how the Trika elaborates a monism made immune to any risk that some sort of duality (brahman/māya ) might be reintroduced surreptitiously - a monism thus explicable through and through. ${ }^{92}$

Again, that svätantryaśakti, one of whose realizations is the bhavanakartrta, is said to be nothing else than spanda, itself recurrently equated with sphurattā.

This is what asserts SpN I 1:

citsvābhāvyād acalasyāpi śrībhagavatah svātantryaśaktir [...] kimciccalattātmakadhātvarthānugamāt spanda ity abhihitā,

'The svätantryaśakti of the Lord, though he moves not, being of the nature of consciousness, is known as spanda in accordance with the root-meaning of the word signifying "imperceptible movement" (kimciccalattā).'

The Trika postulates self-awareness in the form of a vibration, or a pulsation, that is, a movement that is not a movement, continuous, yet unchanging, and therefore nearly imperceptible. That this movement be imperceptible is required in order to obviate the objection that the dynamism of the ultimate principle, consciousness, implies its perishability (for activity implies the transformation of the cause, hence its perishability). The 'kimcit' tells us rather that the 'movement' at issue is not otherwise distinguished, which implies that it would be ascertainable only with difficulty, for to perceive it would be to impute to it some characteristics, a direction, an intensity, etc.

\footnotetext{
91 In fact the text refers here to 'sivatattva'.

92 See Bansat-Boudon (2008, pp. 60-62).
} 
İPV I 5, 14 (vol. 1: 256-257) develops this line of thought (apropos spanda, referred to as a synonym for the sphurattā of the verse):

spandanaś ca kiṃciccalanam / eșaiva ca kiṃcidrūpatā yad acalanam api calam ābhāsata iti / prakāśsasvarūpam hi manāg api nātiricyate 'tiricyata iveti tad acalam evābhāsabhedayuktam iva ca bhāti,

"spanda means "imperceptible movement". And this imperceptibility [of the movement] consists in this, that what is surely motionless appears as if in motion. For, although the essential nature of consciousness is not to change, it appears to change; [in other words,] that [essential nature of consciousness] which is motionless appears as endowed with an infinity of manifestations.'

Thus a vast network of correspondences takes shape, tightly meshed, but with a labile structure, one of whose possible patterns would be:

svātantrya $=$ spanda $=$ sphuratt $\bar{a}=$ bhavanakartrt $\bar{a}=$ bhavatt $\bar{a}=$ satt $\bar{a}=$ mahāsatt $\bar{a}=$ aiśvarya $=\bar{a}$ anda $=\bar{a}$ tmaviśrānti $=$ svātantrya - that is, a sovereign, active, beatific freedom.

This sovereignly free agent, animated by his 'energy of action' (kriyāśakti), knows no bounds to his actions, even to the most difficult ones: he is the 'atidurghațakārin' of the İPV II 4, 20 (see Chart), and the one who, as mahāsattā, causes to be what is not evidenced in ordinary "reality". Nothing is impossible, even the oxymoron-he is the paradigm of the jivanmukta, the one "liberated while living' -,${ }^{93}$ even the paradox — as spanda, he is the one who moves without moving -, whereas, as bhavanakartrtā, he exemplifies the grammatical principle according to which 'being' is an 'activity'.

Almost paradoxically, this continuous activity proceeds from, and culminates in, 'repose in the Self', as if Śaivas, in some sort of reinterpretation of the Advaitins' quiescent brahman, conceded that they too have the idea, the notion, of some repose, which then gives rise to wonderment and felicity. They nonetheless differ from the Advaitins on this point, since this 'repose in the Self' is in essence pulsatile, insofar as the Self is spanda.

\section{The Names of the Three Malas, 'Impurities'}

The notion of the triad of impurities (malatraya) appears for the first time in Yogarāja's commentary, while explaining PS 4, which defines the four anḍas:

anyac ca malatrayasvabhāvam mohamayam bhedaikapravaṇatayā sarvapramātrn̄ām bandharūpam pumstattvaparyantadalam māyākhyam aṇdam ity ucyate,

"And another sphere is called $m \bar{a} y \bar{a}$ [anda], the "[sphere of] Illusion", whose essence is the triad of impurities (malatraya). It is composed of delusion (moha); its form is the bondage (bandha) that affects all varieties of cognizers

\footnotetext{
93 See IPV IV 16: Chart.
} 
in virtue solely of its propensity to occasion difference. It consists of that part [of the thirty-six principles beginning with māy $\bar{a}$ and] ending with puruṣa.'

The three 'impurities' (or 'defects' or 'stains') are the anava-, the māylya- and the kārma-malas, generally rendered in English, as 'atomic', 'māyic' and 'kārmic' impurities (and their equivalents, in French) ${ }^{94}$ — the last two of which terms are hardly translations (mere transpositions of the Sanskrit term into English, through the use of an English suffix), and the first is too overwhelmingly "nuclear" for its use here.

Yogarāja enumerates them for the first time in his commentary ad PS 9, while explaining that 'some few cognizers, whose present birth is the last one,' are able to contemplate their own Self, as it is really, that is, as endowed with all the attributes of the Lord himself (omniscience, etc.), in the mirror, now made clear, of their intellect (dhīmukura), namely, in the mirror of their intuition (pratibhāmukura). And such a realization, that is, such a clearance of the mirror of their intellect, can take place only when, by means of the grace of Śiva, the latent dispositions (vāsanā) left by the three malas have been completely removed:

\section{[...] saṃmārjite pratibhāmukura āṇavamāȳȳyakārmamalavāsanāprakṣayāt $[\ldots]$.}

There, that is in the specific context of the nondualist perspective of the Trika, ${ }^{95} \mathrm{I}$ have proposed to translate annavamala as the 'impurity of [deeming oneself] finite', the mayyzyamala as the 'impurity of [regarding the world as] objective', and the kārmamala, as the 'impurity of [supposing oneself the agent of] actions' ${ }^{96}$ The translation reflects, for these three notions, the same point of view, which is that of the fettered subject; the three 'stains' are certainly erroneous, but at the same time are voluntary, imposed on ourselves by ourselves, and by no other, of whatever sort.

The metaphysical explanation of the malas may be thus formulated: once $m \bar{a} y \bar{a}$ śakti, the power of differentiation-which is, by etymology, the energy of delusive construction - ${ }^{97}$ begins to operate, engendering the samsāric world, the five kañcukas constitute the subjectivity of an individual soul (ạ̣u) and affect it with the three impurities. This is the purport of PS 15, which defines māyāsakti as the 'covering of Śiva's own Self' (svātmāvaranam śivasya):

\footnotetext{
94 See in particular Silburn (1957), Torella (1994, p. 199), Sanderson (1992, pp. 288-289), who translates annavamala as the 'Impurity associated with [all] the Unliberated', kārmamala as the 'Impurity of karma', māyiyamala as the 'Impurity of $m \bar{a} y \bar{a}$ '.

95 There are other general Śaiva meanings of the terms, for instance, in the Siddhānta, in which malas (or rather pāśas; see n. 101) are not those 'suppositions' that are implied by nondualism itself. On how the notion of mala evolved in the early period in which the opposition between the Siddhānta and nondualist Śaivism did not yet exist, see Diwakar Acharya's paper in this volume.

96 On those notions, see also PSV 16-18, 24 (quoted infra, p. 80), 37, 57, in Bansat-Boudon and Tripathi (2011).

97 See PSV 15, in Bansat-Boudon and Tripathi (2011): mīyate paricchidyate dharāntah pramātrprameyaprapañco yayā sā māyā viśvamohakatayā vā māyā /, 'māya is so called because by it is constructed/ distributed (mīyate), that is, delimited (paricchidyate), the phenomenal display (prapañca) of knowers and knowns, culminating in earth; or $m \bar{a} y \bar{a}$ is so called in terms of its capacity to delude everyone [and everything].'
} 
paramạ̣ yat svātantryam durghațasampādanam maheśasya / devī māyāśaktị̣ svātmāvaraṇạ̣ śivasyaitat //,

'The supreme freedom of the Great Lord, which accomplishes what is difficult to construe, is indeed nothing but the covering of Śiva's own Self, [in which phase he appears as] the Goddess Māyāśakti-the energy of delusive construction,'

whereas the commentary develops 'śivasya svātmāvaranam' as:

svarūpagopanākhyam āṇavādimalatritayam,

'["Covering of the Self of Śiva"] here refers to the triad of impuritiesimpurity of deeming oneself finite, etc.- - and is termed "concealement of his proper form".'

Thus is demonstrated that $m \bar{a} y \bar{a}$ is responsible for the imposition of the three malas on the infinite Consciousness, or Lord. Likewise, İPvr III 2, 5 observes:

tanmalatrayanirmāṇe prabhor icchā māyāśaktir ucyate,

'The Lord's will to create these three impurities is called "māyāśakti".'

PS 24 applies again the same metaphor of the 'covering' (āvarana) to the three malas (see infra, p. 79) in the context of the Lord's joyful playing at hiding from himself. Thus malas are but another modality of the movement of constriction that the essentially ubiquitous and free Śiva imposes on himself: ${ }^{98}$ not only, it is māya and the five kañcukas, 'cloak, sheath', which establish the triad of the malas (PSV 15; İPvr III 2, 5), but malas themselves are described as kośas, 'sheaths' (PS 24, quoted infra) and samkocas, 'constrictions' (PSV 63, quoted infra, p. 80; PHvr 9, quoted infra).

PS 16-17 deals with the purusatattva (there called pumstattva) and the hexade formed of $m \bar{a} y \bar{a}$ and the five kañcukas. It is worth noting that Jayaratha quotes PS 16cd-17 in his commentary on the passages of the Tantrāloka (TĀ V ad I 39-40) that expound the doctrine of the double ignorance (TA $\bar{A}$ I 36ff.): 'spiritual' (paurușājñ̄ana) and 'intellectual' (bauddhājñāna)—along with its positive counterpart, the doctrine of the double awakening: 'spiritual' (pauruṣajñāna) and 'intellectual' (bauddhajñāna). ${ }^{99}$

Although the Paramārthasāra refers not to these symmetric pairings, one may infer, from the citations that Jayaratha makes of PS 16cd-17 in this particular context, that this pair (paurușājñānalbauddhājñāna) corresponds in the Paramārthasāra to the conjoined placement of finitude (v. 16-17) and double error

\footnotetext{
98 This movement of constriction is expressed through recurrent terms such as kośa, samkoca, and other derivatives from the root $k u c$, and through such major notions of the system as kañcukas and andas, as well—which, as we have seen, means literally 'egg, sphere'; see supra, p. 62, 63 and n. 55.

99 The Siddhānta knows the notion; see Sanderson (1992, p. 287; 1995, p. 44). In the context of nondualist Kashmirian Śaivism, if the rationale for these concepts is present in the Śaiva Āgamas, the terminology, which presents overtones of the Sāmkhya, appears mainly in the Tantrāloka. It is noteworthy that, while reinterpreting those concepts in the nondualist perspective of the Trika, Abhinavagupta rearranges them according to a well-organized and symmetrical scheme. On the notions of paurușajjñana / bauddhājñāna and paurușajñāna / bauddhajñāna in the Trika, see Bansat-Boudon and Tripathi (2011, pp. 42-43).
} 
(v. 30-31), inasmuch as 'spiritual ignorance' (paurușājñāna) is but the metaphysical ignorance proper to incarnate man, which consists in mistaking the Self for the nonSelf-first level (or degree) of error, as developed in PS 24 and 30-, whereas 'intellectual ignorance' consists in mistaking the non-Self (such as the body, as when one says: 'I am slim, I am fat') for the Self-second level of error, as developped in PS 31.

It thus may be postulated that i) the paurușājñāna corresponds to the anavamala, the impurity of deeming oneself finite, that is, the wholly deceitful 'atomization' of universal consciousness - itself the product of $m \bar{a} y \bar{a}$ (PS 15) - and to the constitution of the purușa, finite (or mundane) man (PS 16ab); ii) the bauddhājñanna corresponds to the quintuple constriction of the kañcukas (PS 16cd-17).

It is PS 24 that first offers a complete exposition of the malas:

\section{paramāvaraṇam mala iha sūkșmam māyādikañcukam sthūlam /}

bāhyam vigraharūpam kośatrayaveștito hy ātmā //,

'In this world, the supreme covering is the impurity [also termed anavamala]; the subtle one consists of the [sixfold] sheath, beginning with $m \bar{a} y \bar{a}$ [thus constituting the māyiyamala]; the gross covering is external, and has the form of the body [thus constituting the kārmamala]. Indeed the Self is enwrapped in a triad of coverings.'

The annavamala, 'impurity of deeming oneself finite', is the fundamental, ontological impurity, that 'related to the anu' (cf. the 'atom' of the Vaiśeșika- the smallest particle found in "nature"). It represents the reduction of infinite free Consciousness to an infinitesimal, 'atomic', state (cf. PS 24), and corresponds to the first degree, or level, of error (see PS 24 and 30, and supra), namely, the fundamental misapprehension of taking the Self for the non-Self, expression of 'nescience' (avidyā), termed as well 'ignorance' (ajñāna). In other words, that first level of error consists in Self-forgetfulness (when the cognizing subject forgets he is none other than the Lord, who is full in all respects) and in the advent of subjectobject dualism in the form of 'dualizing thought' (vikalpa, PS 25). ${ }^{100}$

Therefore, in the realm of experience, as stated in the Śivasūtravimarśinī [ŚSV] I 4, the annavamala is the 'presumption (or intuition) of limitedness' (apürnammanyatā), which makes the limited soul think: apürṇo 'smi, 'I am not full' [viz., 'I am imperfect'] (ibid.) — which is the very content of the first level of error as described in PS 25 and 30 (as well as in PSV ad loc.).

The anavamala is so intrinsic to the finite soul that it is considered as the impurity par excellence, so much so that the term mala alone is enough to represent it, ${ }^{101}$ by synecdoche, as is the case in PS 24, which defines it as the 'supreme covering' (paramam āvaranam). As explained by PSV ad loc.:

\footnotetext{
$\overline{100}$ PS 31 deals with this notion of a double error, the second error expanding on the first: timirād api timiram idam ganḍasyopari mahān ayam sphoțh [...]. 'It is darkness upon darkness, it is a great "pustule upon a boil" [...]'); see Bansat-Boudon and Tripathi (2011, pp. 166ff., 191 (n. 848)).

101 A usage that occurs already in the Siddhānta (which, nevertheless, knows of the three impurities, usually called the three pāśas, namely: mala, karman and $m \bar{a} y \bar{a}$ ), where the notion of mala equals the annavamala of the Pratyabhijñā, yet with the fundamental difference that, in the dualist Siddhānta, the mala is conceived of as a material substance (dravya), outside consciousness, therefore unperceived
} 
[...] svarṇasya kālikeva param antarañgam āvaraṇam tādātmyena sthitatvāt, "By "supreme" cover is meant "existentially included [in the finite soul]" (antaranga), for it remains as coexistent [with consciousness] (tādātmya) in the manner of the flaw within the gold $(k \bar{a} l i k \bar{a})$,'

- a recurrent analogy, in PSV, as regards the annavamala (see PSV 87-88).

The use of the metaphor and of the term tâdātmya connotes that, even though it cannot be said why the flaw is within the gold, its presence therein is both irrefutable and 'given' or 'innate' (nija), as stated in PSV 17, in the context of the kañcukas' exposition.

The same passage in the Śivasūtravimarśin̄ defines the māȳyamala, 'impurity of regarding the world as objective', as the 'display of differentiated objectivity' (bhinnavedyaprathā), which makes the finite being consider his body (or his vital breath, prāna or his wife and sons, as will be stated in PSV 68 quoted infra, p. 82) as if it were his Self, such that he thinks: kșāmah sthūlo vāsmi, 'I am slim or fat' (ibid.)_and this is the very content of the second level of error as described in PS $31 .^{102}$

Again, ŚSV I 4 defines the kārmamala, 'impurity of supposing oneself the agent of actions', as the 'impregnating [of consciousness] with the dispositions that result from one's good and bad [actions]' (śubhāśubhavāsanā), which makes the finite being think: agniștomayājy asmi, 'I am a performer of the agniștoma sacrifice' (ibid.) — thus is the kärmamala responsible for the endless cycle of transmigration. ${ }^{103}$

As stated in PSV 63:

bhāvanayeyam sarvataḥ pūrṇāpi citiśaktir ānavamāȳyamalamūlena kārmamalenāghrātā saṃkucitā vyāpiny api ghațākāśavat ...,

'It is through this efficient force (bhāvanā) [unleashed by ritual acts undertaken in this life, whose result is a future body suitable to the fulfillment of those acts] that the energy of consciousness (citiśakti), although replete in all respects, is affected by the impurity of supposing oneself the agent of actions (kārmamala), which itself originates in the impurities of deeming oneself finite (ạnavamala), and of regarding the world as objective (māyiyamala); this energy, though all-pervasive, becomes thus delimited (samkucita) just as does the space within the jar.' 104

The passage makes it clear that the anavamala is the matrix from which proceed successively the two others-the mäyiyamala and the kärmamala.

Note that, in the context of the exposition of the 'seven Subjects' (saptapramātrs), ${ }^{105}$ IPK III 2, 4 introduces a subtle splitting within the annavamala itself:

svātantryahānir bodhasya svātantryasyāpy abodhatā /

\footnotetext{
Footnote 101 continued

(see Sanderson 1995, pp. 39, 44; Goodall 2012, s.v. pāśa). For the formation of the notion of mala as removable material impurity, see also Diwakar Acharya's paper in this volume.

102 Same description of the experience in PSV 31, although the exegete does not relates it explicitly to the māyiyamala.

103 PHvr 9 gives the same definitions of the three malas as those of the ŚSV.

104 Text and translation of v. 63, infra, p. 89.

105 On the 'seven Subjects' (or 'Cognizers'), see Bansat-Boudon and Tripathi (2011, pp. 189, 330).
} 
dvidhānavam malam idam svasvarūpāpahānitạ̣ //,

'Consciousness that is devoid of freedom and, vice versa, freedom devoid of consciousness: these are the two forms of the impurity named anava-so called because it obliterates one's own true nature., 106

- a splitting that accounts for the two levels of error inherent in the finite condition: when there is omniscience without omnipotence, one is led to take the Self as the non-Self, that is, to consider oneself as incomplete (apūrnammanyatā); when there is omnipotence without omniscience, one is led to consider the non-Self (body, breath, etc.) as the Self (anātmany àtmatābhimānah). This is, in effect, the exegesis which ŚSV I 2 gives of İPK III 2, 4 before quoting the passage. Despite being very elliptic, ŚSV I 2 does shed light on the rather cryptic wording of IPK III 2, 4:

tatra cidātmany api [...] apūrṇammanyatāmātrātmanā rūpeṇa / svātantrye 'pi dehādau abodharūpeṇa anātmany ātmatābhimānātmanā rūpeṇa dviprakāram ạnavamalam $[\ldots] .{ }^{107}$

Having referred to ŚSV I 4 in order to justify my translation of each of the terms affected to the three malas, I should point out that ŚSV I 4 is only a condensed rewording of IPK III 2, 5 and its Vrtti: Kșemarāja is paying tribute to his parameșthin, Utpaladeva. I shall just quote İPvr III 2, 5:

atraiva dvidhānave vedyam abhinnam api bhedena yadā bhāti tadāto 'pi viparyasād nāmnā māȳyam malam / ahetūnām api karmaṇạ̄n janmādihetubhāvavișayaviparyāsād abodhātmakakartrgatạn kārmam /,

'When, there being this twofold annava[mala], objective reality, though not different [from the subject], yet appears as different from him, it follows that indeed the māyiyamala is due to that error. And the kārma[mala], which pertains to the cognizing subject characterized by his lack of consciousness, is due to the error that consists in considering his actions as the impelling cause of [the endless cycle of] rebirths, etc., whereas such actions are not causes, by all means [the only cause of bondage or liberation being the sole Lord]. ${ }^{108}$

Such a text allows one to understand that the mäyiyamala is the 'impurity of regarding the world as objective', and that the kärmamala is the 'impurity of supposing oneself the agent of actions', as I propose to translate, inasmuch as the cause of transmigration is not the acts, whatsoever, of the finite soul, but the Lord himself who plays at subjecting himself to transmigration, as a finite soul.

Kṣemarāja, commenting on his PH 9, goes even further, presenting the three malas as limitations (saṃkoca, or parimitatā) of the icchā, jñāna and kriyā śaktis, respectively:

icchāśaktị̣ saṃkucitā sat̄̄ apūrṇaṃmanyatārūpam āṇavam malam / jñānaśaktih [...] antaḥkaraṇabuddhīndriyatāpattipūrvam atyantam samkocagrahaṇena bhinnavedyaprathārūpam māyīyạ̣ malam / kriyāśaktih [...]

\footnotetext{
106 Transl. Torella (1994), sligthly modified.

107 See Singh (1988, p. 19).

108 Translation is mine. There is no other impelling cause (hetu) of whatever action than the Lord, as we have seen apropos the notion of bhavanakartrtā (see supra, p. 64).
} 


\section{karmendriyarūpasaṃkocagrahaṇapūrvam atyantam parimitatām prāptā} śubhāśsbhānuṣthānamayam kārmạ̣ malam /,

'icchāśakti, once contracted, becomes ānavamala, which consists in considering oneself imperfect; jũānaśakti, assuming the extreme contraction that begins with the acquisition of the inner organ and cognitive organs, becomes māylyamala, which consists in the "display of differentiated objectivity" [i.e., of the apprehension of objects as different from one another and from the Self]; kriyāśakti, once contracted in the form of organs of action, becomes extremely limited, assuming the form of kārmamala, which consists in doing good and evil.'

It is noteworthy that such a term-for-term correspondence of the three malas to the three śaktis constitutive of Śiva's triśūla implies as its background the correspondence of both the triads to a particular distribution of the tattvas: purusa and kañcukas corresponding to the icchäśakti and the anavamala, the antahkarana and the buddhindriyas, to the jñanaśakti and the māyiyamala, the karmendriyas to the kriyāśakti and the kārmamala.

Moreover, the PHvr quoted above confirm that the three malas proceed from one another, as do the three śaktis, according to the Mālinivijayottaratantra [MVT] (III 5-9a). ${ }^{109}$

PSV 68 introduces an interesting variant in the basic formulation of the paśu's experience corresponding to each mala:

\section{[...] 'sakalavikalpān' paśur asmi karmabandhabaddho deharūpī mamedam putradārādy amunā karmaṇā svargo nirayo vā bhaviṣatītyādi sarvāḥ kalpanā aham evedam sarvam iti parāmarśaśeșībhūtāh [...] 'juhvat', \\ '[...] "by pouring" (juhvat) "all thought-constructs" (sakalavikalpa), [the author] means that all such suppositions (kalpanā) as "I am a bound soul, tied up in the bondage of actions", "I am my body, these are my sons, my wife, etc.", or "this act will lead to heaven or hell, etc.", are set aside in the [jūānin's] awareness (parāmarśa) that "It is I who am all this".'}

In Yogarāja's exegesis, these contents of experience stand respectively for the annavamala ('I am a bound soul, tied up in the bondage of actions'), the māyinamala

\footnotetext{
$\overline{109}$ MVT III 5-9a, quoted in both SpN III 13 and ŚSV III 19, clearly develops: yā sā śaktir jagaddhātuh kathitā samavāyin̄̄ / icchātvam tasya sā devī sisskșoḥ pratipadyate // saikāpi saty anekatvam yathā gacchati tac chrṇu / evam etad iti jñeyam nānyatheti suniścitam // jñāpayantī jagaty atra jñānaśaktir nigadyate / evam bhavatv idam sarvam iti kāryonmukh̄̄ yadā // jātā tadaiva tad vastu kurvaty atra kriyocyate / evam eșā dvirūpāpi punar bhedair anantatām / arthopādhivaśād yāti cintāmaṇir iveśvarī //, 'When the Master of the world wishes to create, his [supreme] Śakti, the Goddess who is said to be inherent in him, becomes Will [viz., energy of Will]. Listen how she, though one, becomes many. Similarly, when she makes the knowable known as definitely "this" and not as something else, she is named in this world "energy of Knowledge". Similarly, when she becomes intent on acting, considering: "Let all this come to be [just as I have willed and known it]", [that same energy], arisen at the very moment she creates the object, is then named the "[energy of] Action". Thus, though [already] of two forms [Knowledge and Action], she differentiates herself again, becoming innumerable, thanks to those objects, which [function as her] contingent attributes. Therefore, this sovereign Goddess is to be compared to the thought-gem that yields all desires.'
} 
('I am my body, these are my sons, my wife, etc.') and the kārmamala ('this act will lead to heaven or hell, etc.'). ${ }^{110}$ Additionally, the three malas appear there as the very example of the vikalpas which the yogin pours as an oblation into the blazing fire of his consciousness, fanned by the winds of his bhāvan $\bar{a}$ (see the text of PS 68, infra, p. 87). This establishes a connection between the three malas and the experience of bhāvanā, defined here as 'the awareness (parāmarśa) that "It is I who am all this" (aham evedam sarvam) ', ${ }^{111}$ which is discussed in the following section.

Now, a hypothesis: might it be possible to see in these three terms, displaced to a more concrete level, references to the three forms of being identified above, while examining bhavanakartrtā-viz., sattā, bhavattā, bhavanakartrtā ? The ānava defect relates, in effect, to the individual subject [= sattā $]$; the māyzya- to the objective universe [= bhavattā]; and the kärma- to the cycle of existences, which, by means of the notion of the act, explains the fashion in which the two other modes of being enter into contact, entwine together [= bhavanakartrta $\left.{ }^{112}\right]$.

\section{Bhāvanā, 'Meditative Realization'}

There are two main meanings of the term bhāvanā based on its derivation from the causative bhāvayati (bhāvanā is 'that which causes to be', 'that which brings into being'), namely:

i) In the Mīmāṃsā, the technical and restricted meaning of bhāvanā is 'efficient force' when referring to an action, especially one of a ritualistic nature, where bhāvanā is generally viewed as instrumental in bringing about the result of that action (so Edgerton, F., Mìmāmsānyāyaprakāśa, q.v.). Yet this "practical” function of bhāvanā takes second place. Being an 'exegesis' of the Vedas and a philosophy of ritual action, the Mīmāmsā first concerns itself with the injunction to act (vidhi), in the context of ritualistic actions. Therefore bhāvana $\bar{a}$ is primarily the efficient force inherent in injunctive utterances, for instance in the form of the optative affix - a linguistic force, as it were, that causes the addressee to obey the injunction. Accordingly this first level of bhāvanā is called 'verbal' (śābdì bhāvanāa).

Secondly, bhāvanā also brings into being the fruit promised by the injunction, as a reward for implementing the enjoined action-this is 'real' bhāvanā (ārthī bhāvanā). For example, in svargakāmo jyotiștomena yajeta ('Let he who aspires to heaven make a sacrifice by performing the jyotiștoma ritual'), the fruit expected of the prescribed sacrifice is heaven; and, as the Mīmāmsā points out, although it may take some time, the arrival of the fruit is assured. ${ }^{113}$

The Mīmāmsaka analysis therefore looks at the whole process: what guarantees the ultimate efficacy of prescriptive speech-i.e., beyond the performance of the

\footnotetext{
110 See my analysis of the text in the context of examining bhāvanā, infra, p. 87.

111 An experience also expressed as 'sarvam brahmāsmi', 'It is I who am all this,' as stated in PSV 71.

112 See supra, p. 8, my analysis of the notion of bhavanakartrtā as that which articulates the intimate connection of doing and being, making the supreme principle-Consciousness as deity-the agent of both being and becoming [i.e., becoming the phenomenal world].

113 See Kane (1962, pp. 1235-1240).
} 
ritual itself, the fact that the fruit promised by the injunction is actually awarded-is the force intrinsic to the act of speech, a coercive, illocutionary force which owes as much to the presence of injunctive morphems as to the explicit naming in the injunction of the desired fruit (in this instance, heaven) at the source of the ritual process. Indeed, in the final analysis, the efficacy of the action is measured by obtaining (even with some delay) the reward for which that action has been performed.

The bhävan $\bar{a}$ is therefore regarded as a power, a sort of energy intrinsic to the text itself and its injunctive modalities expressed by the optative affix morphem. The conception of bhâvanā as energy intrinsic to language (what pragmatics would call its 'illocutionary' force) made it particularly suited to integration within the essentially dynamic ontology of nondualist Kashmirian Śaivism, characterized by the omnipotence of Energy and its countless manifestations. This will be the point of this section of my paper.

ii) Outside the Mīmāmsāa, bhāvanā has the general and wider meaning of 'meditation', in the sense that meditation is what 'brings into being' the object of the meditative practice, what 'causes it to be'. Saiva speculations go even further: bhâvana is not merely the meditation that makes its object appear, it is that which causes one to be the object of one's own meditation. In other words, the Saivite bhāvanā is a reflexive notion where the object of meditation is absorbed into the meditating subject, so that the process culminates in the 'realization of nonduality' (advaitabhāvanā) as stated in PS 41. Furthermore, although it is the result of a practice, realization comes abruptly, like a sudden, illuminating revelation. This is connoted by the recurrent use of the roots sphur / sphut to describe an experience that borders on wonderment, in particular the 'wonderment of supreme ipseity' (parāhantācamatkāra), ${ }^{114}$ the final stage of the quest for liberation. This is why I suggest that bhāvanā should be translated as 'meditative realization'. ${ }^{115}$

Interestingly, Abhinavagupta's Paramārthasāra contains the two main meanings of the term: 1. 'meditative realization' in vv. 41 (as bhāvana, in neuter), 52 and 68 (see the respective texts, infra, p. 85-87), in the context of liberation, more precisely of 'liberation in this life' (jīvanmukti), and 2. 'efficient force' in v. 63, in the opposite context of bondage and the paśu's submission to the law of karman and transmigration.

iii) Outside the Mīmāmsāa and the nondualist Śaiva corpus, the notion also occurs for instance in the Paramārthasāra attributed to Ādiśeșa [ĀPS], which is claimed by Abhinavagupta, in his own Paramārthasāra, to be a Śaiva rewriting on the grounds that the earlier text constitutes a kind of pre-Śankara Vedānta, a conflation of Sāmkhya dualism and the nondualism of the Vedānta, in addition to its professed devotion to Viṣnu.

From the viewpoint of history of ideas, it would be interesting to establish how the Saiva notion of bhāvanā, such as it occurs in the second Paramārthasāra, was directly inherited from the earlier text of Ādiśeșa, irrespective of its subsequent transformations. Leaving that aside, we shall see that what is at play in the transition

\footnotetext{
${ }^{114}$ On this notion, see Bansat-Boudon and Tripathi (2011, p. 71 (n. 272)).

115 On bhāvanā in other systems of thought, see Chenet (1987).
} 
from the first to the second Paramārthasāra is a process of refinement and added emphasis (to the point of theorisation) rather than an actual transformation.

Let us examine the uses of the notion in the earlier Paramārthasāra, where the means by which one accedes to the ultimate knowledge of the Self (or of brahman) is 'meditation' (bhāvanā), according to the usual translation (see Danielson). My suggestion is that, in the first Paramārthasāra, the term bhāvanā should be understood as 'meditative realization', as is the case in the second Paramārthasāra. It is worth noting that Danielson himself, in his translation of the earlier Paramārthasāra, was somewhat indecisive as he chose to translate the verb bhāvayati as 'to realize' (v. 57) but the noun bhāvanā as 'meditation' (v. 58-59).

Ādiśeșa's Paramārthasāra devotes three verses (57-59) to the bhāvanā:

evam dvaitavikalpam brahmasvarūpām vimohanīm māyām /

utsrjya sakalanișkalam advaitam bhāvayed brahma //

yadvat salile salilam kṣīe kșīram samīraṇe vāyuh /

tadvad brahmani vimale bhāvanayā tanmayatvam upāyati //

ittham dvaitasamūhe bhāvanayā brahmabhūyam upayāte /

ko mohaḥ kạ̣ śokaḥ sarvam brahmāvalokayataḥ //,

'After one has discarded Illusion, which, being delusive, has the nature of fallacy [in that it produces] the idea of plurality, let him realize (bhâvayet) brahman, which is without plurality, being both with and without parts. As water becomes one with water, milk with milk, wind with wind, so, by meditative realization (bhāvanā) on the spotless brahman, [man] becomes one with it. If in that way, the sum total of plurality has receded into the state of brahman by meditative realization (bhāvanā), no delusion, no sorrow [remains] for him, as he looks on everything as brahman., ${ }^{116}$

The bhāvanā is also the means privileged in the Saiva Paramārthasāra, to the extent that it is prevalent in the s'áktopayya, the 'way of energy'-that of the four 'ways' whose perspective is preferred by Abhinavagupta in his Paramārthasāra. ${ }^{117}$ There, the term bhāvanā first occurs in v. 41 in the compound advaitabhāvana, where the neuter (bhâvana) appears instead of the more common feminine form, both in the verse (probably for metric reasons) and the commentary. It should be noted that v. 41, where bhävana $(-n \bar{a})$ occurs for the first time, has no parallel in $\bar{A} P S$, probably because the notions at issue there, like the whole context (vv. 4146), pertaining to Śaiva mantric practice (mantrasampradāya; avat. ad 43), are purely Śaiva: ${ }^{118}$

prthivī prakrtir māyā tritayam idạ̣ vedyarūpatāpatitam / advaitabhāvanabalād bhavati hi sanmātrapariśeșam //,

\footnotetext{
116 ĀPS 57-59. Transl. Danielson, modified as for the rendering of bhāvanā (1980).

117 On the śäktopāya and its association with bhāvanā, see Bansat-Boudon and Tripathi (2011, pp. 49, 193 (n. 858), 243 (n. 1099)).

118 On mantric practice and its association with bhāvanāa, see notably Bansat-Boudon and Tripathi (2011, p. 198 (n. 880)).
} 
'For the triad of Earth, Nature and Illusion, erroneously consigned to the status of "that which is to be known", becomes, by the force of the realization of nonduality (advaitabhāvana), a residue of pure Being.'

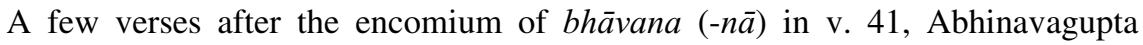
condenses the teaching given by his predecessor (in vv. 57-58, quoted above) into a single verse (v. 51):

\section{ittham dvaitavikalpe galite pravilanghya mohanīn māyām /}

salile salilam kṣīre kșìram iva brahmaṇi layı̄ syāt //,

'Thus, once the postulation of duality has ceased, [the adept] after overcoming the bewildering power of illusion, should merge in brahman as milk merges in milk, and water in water,'

and in concatenation he reproduces (in v. 52) verse 59 of the first Paramārthasāra, verbally modified to suit Saivite metaphysics:

ittham tattvasamūhe bhāvanayā śivamayatvam abhiyāte /

kah śokah ko mohah sarvam brahmāvalokayatah //,

'Thus, once the host of principles has been reintegrated into Siva through meditative realization, what sorrow is there, what delusion for him who views everything as brahman?'119

The PSV comments:

[...] galitakañcukabandhasya yoginaḥ 'tattvasamūhe' bhütavișayendriyavrāte 'bhāvanayā' sarvam idam ekā svasamvid iti drdhapratipattyā 'śivamayatvam' prāpte paramādvayarūpatām 'yāte' [...],

'[...] when-for the yogin whose bonds, the sheaths, have fallen off-the "host of principles", namely, the group of sense-organs [as instruments of subjectivity] and their domains, the elements, "has been reintegrated into Siva", "through meditative realization" (bhāvanā) — that is, through the firm understanding that this universe is [identical with] his own unfragmented $(e k \bar{a})$ consciousness-[when, in other words, the yogin] has attained the state of ultimate nonduality (paramādvayarūpatā) [...].'

For its part, the first Paramārthasāra returns (v. 64) to the notion of bhāvanāa, in the guise of the causative verb bhāvayati, which it associates with the idea of liberation (parameśvarıbhütah, 'he becomes the Supreme Lord'):

àtmaivedam sarvam niṣkalasakalạ̣ yadaiva bhāvayati / mohagahanād viyuktas tadaiva parameśvarībhütah //,

\footnotetext{
119 Note especially the substitutions siva for brahman, tattva ${ }^{\circ}$ for $d v a i t a^{\circ}$. The second hemistich, in both texts, recalls Ísopanisad 6-7-the first PS being somewhat closer to its source, since it respects the Upaniṣadic order of the words (ko mohah kaḥ śokah): yas tu sarvāṇi bhūtāny ātmany evānupaśyati / sarvabhūteșu cātmānam tato na vijugupsate // yasmin sarvāṇi bhūtāny ātmaivābhūd vijānata / tatra ko mohah kah śoka ekatvam anupaśyatah //, 'And he who sees all beings in his own self and his own self in all beings, he does not feel any revulsion by reason of such a view. When, to one who knows, all beings have, verily, become one with his own self, then what delusion and what sorrow can be to him who has seen oneness?' (transl. Radhakrishnan).
} 
'Only when one realizes [this Self] as both having and not having parts, does one become free from the impenetrable darkness of Delusion, and become Supreme Lord at the same time.'

And, although it does not mention it explicitly, ĀPS 66 gives a good etymology of the term:

sarvākāro bhagavān upāsyate yena yena bhāvena / tạn tạ̣ bhāvam bhūtvā cintāmaṇivat samabhyeti //,

'By whichever appearance the Lord, who has all forms, is meditated upon, that appearance he adopts, as he is like a jewel [fulfilling all] wishes.' ${ }^{120}$

Similarly, in v. 68, the second Paramārthasāra again associates the notion of bhāvana with that of liberation:

ittham sakalavikalpān pratibuddho bhāvanāsamīraṇatah /

àtmajyotiși dīpte juhvaj jyotirmayo bhavati //,

'Thus awakened by the winds of his meditative realization, as he pours an oblation of all his thought constructs into the blazing Fire of the Self, he becomes Fire itself.'

The PSV ad loc. comments:

[...] yā bhāvanā aham eva caitanyamaheśvarah sarvātmanā sarvadaivam sphurāmìti yātmani vimarśarụ̣̈hih saiva [...],

'[The term] meditative realization (bhāvanā) is used [here by us, Śaivas] as conventionally synonymous with 'awareness' (vimarśa), in the context of the Self [as justified by the insight]: "It is I who am the Great Lord in the form of consciousness, who manifest (sphurāmi) ever thus, intensely" [...],'

then goes on to define bhâvanā in nearly identical terms (see the passage quoted, supra, p. 82), by describing bhāvanā as "the awareness that "It is I who am all this", (aham evedam sarvam iti parāmarśah).

It should also be noted that, in Abhinavagupta's Paramārthasāra, the metaphor of the 'winds of meditative realization', which serves as a matrix for the extended metaphor in the verse, is possibly a reuse of a segment from v. 58 of Ādiśeșa, not otherwise utilized-[...] samīraṇe vāyuh, 'As [...] wind becomes one with wind'given that v. 51 of the Śaiva Paramārthasāra has only kept the two initial images of water and milk in its exercise of transposition.

The Śaiva Paramārthasāra thus puts equal emphasis on the idea of bhāvanā, with the difference that here the notion is placed among practices of an Ägamic yoga, by which the Trika sets great store. Associated with mantric practice, kundalinīyoga and the practice of the mudrās, bhāvanā is the spiritual exercise par excellence, through which the mumukșu simultaneously accedes to knowledge and liberation while still alive. ${ }^{121}$

The aim and result of mantric practice and bhāvan $\bar{a}$ are the conversion of the discursive mode of thought into intuitive and non-discursive awareness focused (if that

\footnotetext{
120 This verse lacks a correspondent in the later Paramārthasāra.

121 See PSV 9, 61, 62, 64-66, 83, 86, 96.
} 
is the appropriate word) on ultimate reality - an awareness of 'difference-and-nondifference' (bhedābheda). ${ }^{122}$ In the same way, mantric practice and bhāvanā are concerned with the internal sacrifice (antaryāga) as inherited from the Kaula tradition, ${ }^{123}$ which involves the promise of liberation in this life. ${ }^{124}$ 'Internal sacrifice', extolled by the śaktopāya, ${ }^{125}$ defies description and can at best be described by analogy. Thus vv. 74-80 of the Śaiva Paramārthasāra metaphorically transform the processes of the 'mundane' ritual into their internal counterparts-in other words, from practices specific to the annavopāya into ones suitable to the śāktopāya. ${ }^{126}$

The Śaiva meaning of bhāvanā is thus firmly established in Abhinavagupta's Paramārthasāra and its commentary. The following chart lists the various formulations of the content of the experience and clearly establishes that bhâvana $=$ vimarśa / parāmarśa (v. 68) = sphurattā (in the form of the corresponding verb; PSV 68): ${ }^{127}$

Verse PS PSV

$41 \quad[\ldots]$ advaitabhāvanābalāt $[\ldots]$

52 ittham tattvasamūhe bhāvanayā śivamayatvam abhiyāte /

kah śokah ko mohah sarvam brahmāvalokayatah //,

'Thus, once the host of principles has been reintegrated into Śiva through meditative realization, what sorrow is there, what delusion for him who views everything as brahman?'

68 ittham sakalavikalpān pratibuddho bhāvanāsamīranatah /

ātmajyotiși dīpte juhvaj jyotirmayo bhavati //,

'Thus awakened by the winds of his meditative realization, as he pours an oblation of all his thought constructs into the blazing Fire of the Self, he becomes Fire itself.'

[...] 'tattvasamūhe' [...] 'bhāvanayā' sarvam idam ekā svasamvid iti drḍapratipattyā

'śivamayatvam' prāpte paramādvayarūpatām 'yāte' [...],

'[...] when the host of principles has been reintegrated into Śiva "through meditative realization" (bhāvanā) — that is, through the firm understanding that this universe is [identical with] his own unfragmented consciousness-[when, in other words, the yogin] has attained the state of ultimate nonduality (paramādvayarūpatā)[...].'

1. [...] yā bhāvanā aham eva caitanyamaheśvarah sarvātmanā sarvadaivam sphurāmīti yātmani vimarśarūdhih saiva [...],

'[The term] meditative realization (bhāvanā) is used [here by us, Śaivas] as conventionally synonymous with 'awareness' (vimarśa), in the context of the Self [as justified by the insight]: "It is I who am the Great Lord in the form of consciousness, who manifest (sphurāmi) ever thus, intensely" [...].'

2. [...] aham evedam sarvam iti parāmarśaśah,

'[The bhāvanā; to be supplied] is the awareness that "It is I who am all this".'

\footnotetext{
$\overline{122}$ On this notion, see PS 12-13 (and its commentary), as well as avat. ad PS 41 and 46.

123 The antaryāga exists everywhere as internal worship. But it becomes the only way of worship in some Kaula branches.

124 See TĀ IV 211 (antaryāga) and 212 (description of the jiv̄anmukta).

125 See TĀ IV 211 and PS 41-46, 74-80.

126 See the analysis of the metaphoric process in Bansat-Boudon and Tripathi (2011, pp. 28, 252-280).

127 See also TĀ IV 14 and TĀV IV 13, infra, p. 92.
} 
Nevertheless, in v. 63, Abhinavagupta does retain the Mīmāmsaka meaning of the term bhāvanā, that of 'efficient force', given the context of the exposition of the law of karman, which results in the endless cycle of transmigration:

\section{parimitabuddhitvena hi karmocitabhāvidehabhāvanayā /}

saṃkucitā citir etaddehadhvamse tathā bhāti //,

'Indeed, energy of consciousness, delimited by the efficient force (bhāvanā)

[unleashed by ritual acts undertaken in this life, whose result] is a future body suitable to [the fulfillment of] those acts-acts that are themselves made possible by limiting the intellect [to egocentric purposes]-comes into possession of a new body, once this present body has fallen away.'

My interpretation is therefore different from those of previous translators (my italics for their following translations of bhāvanā): cf. Barnett (1910): 'Owing to the conception of a future body corresponding to [present] works, [a conception] arising from limitation of intelligence, the Thought becomes accordingly contracted on the dissolution of the present body;' Silburn (1957), echoing Barnett: 'En effet, grâce à la faculté qu'elle possède d'imaginer un corps futur conforme à l'acte (qu'elle accomplit) en mettant en œuvre un intellect limité, la conscience se contracte proportionnellement à la dissolution du corps actuel;' Pandit (1991): 'An individual finite I-consciousness, having a deep rooted conception of finitude with regard to itself, is lead (sic) by the impression of its future body, formed in accordance with its deeds, to the consequent position after the end of its current form.'

Ignoring (deliberately?) both the specifically Saiva meaning of bhāvanā as the spiritual realization preceding mokșa itself and its Mīmāmssaka acceptation, these three interpretations appear to retain the more general meaning (futher on developed in Indian poetics) of 'conception', 'imagination'. Nevertheless, the Mīmāmssaka acceptation, here, in v. 63, is beyond doubt, since the notion appears in the context of the law of karman and transmigration. For, according to the Mīmāmsā, the act does not end with its material result (which may be nothing more than the sacrificial ashes): it goes on through its 'efficient force' until the moment of "real" fruition when the wish of the performer is granted. Even this "real" result is dependent on the 'efficient force' generated by the preceding ritualistic act.

It should nevertheless be pointed out that those who question this sacrificial model (cf. BĀU VI 2, 15-16; MuU I 2, 5-11) have noted that, because the preceding (ritualistic) act is occasional and impermanent, its 'efficient force'necessary to keep the sacrificer 'in heaven', for example-cannot in itself be regarded as permanent and must in turn be destined to exhaustion, thereby becoming but another element in an endless series of impermanent causes and effects.

Further on, PSV 63 emphasizes that, in the context of the finite soul subjected to transmigration, the 'efficient force' is articulated through the $v \bar{a} s a n \bar{a}$ s produced in the mind by ritualistic actions:

[...] citiśaktir [...] karmānugunaphalabhoktrśarīravāsanāvacchedavatī saṃpannā sat̄̄ 'etaddehadhvamse' 'tathā bhavati' /, 
'And so, this energy of consciousness, "once the [present] body has fallen away", still affected by limiting factors such as the latent dispositions (vāsanā) belonging [properly] to the body that enjoys the results following from its actions, "becomes again thus" [that is, comes into possession of a new body].'

In presenting both the Śaiva and Mīmāmsaka meanings of bhāvanā (in v. 41, 52 , 68, and in v. 63, respectively), Abhinavagupta's Paramārthasāra offers an opportunity to understand them not only as different but also as symmetrical. Indeed it is to be inferred from a close reading of the commentary that v. 68 combines the two meanings, although here the reference to bhāvan $\bar{a}$ in the Mīmāmsaka sense is implicit and should be seen in the mention of the vikalpas as well as in the metaphor of ritual fire. On the one hand, as already noted when discussing the three malas (see supra, p. 82), the vikalpas consumed in the fire of consciousness by the bhāvanā described as a wind fanning the flames are but the three malas responsible for bondage and transmigration. On the other hand, bhāvanā in its Mīmāmsaka sense is the efficient force underlying the third mala, namely kārmamala, the experience of which is described in PSV 68 as 'this act will lead to heaven or hell, etc.' ${ }^{128}$ As such, like the malas, bhāvanā as 'efficient force' is responsible for bondage and transmigration.

Thus interpreted, v. 68 teaches that one bhāvan $\bar{a}-b h \bar{a} v a n \bar{a}$ as meditative realization-dissolves, or rather consumes, the other-bhāvanā as the efficient force of the action, an irrestible power to which the paśu is inevitably subjectedaccording to the metaphoric wording of the verse. In other words, the yogin's awareness of nonduality consumes the efficient force of the act, in the sense that it annihilates the paśu's subjection to the law of karman and transmigration. In this movement of combustion, the mumukșu accedes to liberation, seen in this system as 'liberation in this life'.

The allusion to fire rituals in v. 68 is obvious (whether the homa referred to here is Vedic or Śaiva). Mīmāmsakas have discussed at length the question of the 'efficacy' of the ritual fire, for its consequences were deemed to extend far beyond the cinders that were its only visible result. In PS 68, the 'fire' is interiorized, transformed into pure consciousness and becomes the 'remains' of the combustion of "transitory" states of mind, or vikalpas or malas; in this way, it plays the part of the Mīmāmsaka's 'apūrva' or 'adrșta' that had been regarded as the mechanism through which the 'karman' of the sacrifice (i.e., the sacrifice itself) worked itself out. But this 'adrsțta' has one quality that the Mīmāṃsaka's argued 'adrșta' most significantly lacked: the self-evidence of consciousness.

Additionally, it is remarkable that vv. 63 and 68 form a diptych: in v. 63, bhāvanā in its Mīmāmsaka sense brings about the three malas, resulting in bondage, whereas, in v. 68, bhāvanā meaning 'meditative realization' dispels them (referred to as 'vikalpas' in the verse), thus also dispelling the 'efficient force' of actions,

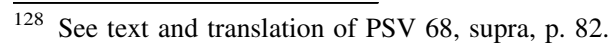


bhāvanā. Not only have we come full circle, but Abhinavagupta's mention of the two bhāvanās in his Paramārthasāra is of some interest for the history of ideas, in that it reveals (admittedly in a somewhat cryptic way) the relationship between the Śaiva and the Mīmāmsaka doctrines. Undoubtedly, the nondualist perspective of the Trika and its proclaimed soteriological intent alter the notion of bhāvanā towards the meaning of the spiritual realization leading one to identify with the supreme principle - the Lord, Consciousness or brahman —, thus making bhāvanā a cause of liberation.

This is probably the reason why Śankara also understands the term bhāvanā occurring in Bhagavadgītā [BhG] II 66 (= II 68, in the Kashmirian recension edited by Gnoli) as: na cāsty ayuktasya bhāvanā àtmajñānābhiniveśah, "There is no "bhâvanā", meaning that there is no entry into [or, aspiration to enter] the knowledge of the Self, for the undisciplined'-which is similar to the Śaiva usage of bhāvanā. Incidentally, Gnoli (admittedly himself the translator of the Śaiva recension of the Gitta) renders the term as 'realization'.

The consequence is that Edgerton's reading of bhâvana as 'efficient force', in BhG II 66, should undoubtedly be understood in a more spiritual sense. One can object to Edgerton's interpretation for two reasons: i) in the technical sense, the Mīmāmsaka notion of bhāvanā applies to the act (and to the 'act of speech'), not to the subject/agent of the act: the 'force' being inherent to the act, it is not legitimate to shift, as Edgerton suggests in his note ad loc., from the idea of 'efficient-force' (sic) to that of 'religious effort', which wrongly involves the subject; ${ }^{129}$ ii) in the Git $\bar{a}$, the context is not about ritual efficiency but about the attainment of 'peace' (śānti, prasāda; see vv. 64-66, 70-71 = 66-67, 72-73 in Gnoli), i.e., the liberation referred to at the very end as brahmanirvāna (v. $72=$ 74 in Gnoli). It is worth noting in this regard that, although Abhinavagupta's Gìtārthasamgraha [GAS] on the Gitā does not comment on the bhāvanā of II 66 [= II 68 in Gnoli], its meaning as 'realization' is suggested, in the text and its commentary, by the recurring use of the term sthiraprajña (and its variants: sthitaprajña, or sthiradh $\vec{\imath}){ }^{130}$ which, in Abhinavagupta's understanding, refers to the yogin 'having attained full knowledge/realization'-equivalent to the Śaiva notion of jūānin (see infra, p.). ${ }^{131}$ Accordingly, Abhinavagupta (GAS II 61-65, in the Kashmirian recension) distinguishes him from the tapasvin or "ordinary" ascetic whose "register" is that of the mere dhyāna, the 'meditation' where the result-the

\footnotetext{
129 'The undisciplined has no (right) mentality, / And the undisciplined has no efficient-force; / Who has no efficient-force has no peace; /For him that has no peace how can there be bliss? /'. Edgerton adds this note to his translation: 'Here, "effective religious impulse"; the word bhāvanā means "bringing to be, tendency to produce something (here religious effort).' It is a technical word of the Mīmāṃsā system [...].' 130 A term which the GAS borrows from the Gìtà (e.g. v. 54, 55, $56=56,57,58$ ).

131 Yet, the term bhāvanā occurs in the first mangala of the GAS, undoubtedly in its Saiva technical sense.
} 
true advent of the object of meditation, that is, himself as not different from the Lord -is never certain. ${ }^{132}$

It should also be noted that, although developed in the texts of the Saiva exegetes, the notion of bhāvanā was inherited from the Āgamas of the Śaiva system, ${ }^{133}$ for instance Svacchandatantra [SvT] VII 259 quoted in SpN (see infra, p. 93) and MVT XVII 20cd quoted in TĀV IV 14 (see infra, p. 93). Vijñānabhairava [VBh] 145 (as quoted in ŚSV III 27, and in Svacchandatantroddyota [SvTU II] 139a) also uses the notion and plays with its etymology (bhāvanā bhāvyate):

\section{bhūyo bhūyah pare bhāve bhāvanā bhāvyate hi yā /}

japah so 'tra svayam nādo mantrātmā japya ìdrśah //,

'Indeed, the realization (bhāvan $\bar{a})$ that is realized again and again within ultimate reality is the [true] recitation (japa); there [viz., within that japa] of itself the sonic resonance ( $n \bar{a} d a$ ) of this sort is to be recited, being of the nature of a mantra. ${ }^{, 134}$

It should be emphasized, in order to further corroborate my understanding of the notion and its translation, that TA $\bar{A}$ II 12-13 distinguishes between bhāvanā, 'realization', and avadhāna, 'concentration', whereas TĀ IV $14 \mathrm{~cd}$ defines it as 'illumination' or 'revelation' by using the verb sphutayet: ${ }^{135}$

sphutayed vastu yāpetam manorathapadād api //,

'[bhāvanā], which reveals ['discloses suddenly'] a reality exceeding the realms of desire [that is, a reality that transcends anything one might imagine] ...'

\section{As TĀV IV 14 points out:}

tarka eva hi parām kāṣthām upagato bhāvanety ucyate,

'When reasoning reaches its ultimate limit, it is called bhāvanā.'

This means that bhāvanā is nothing but the 'ultimate term [or limit]' (parā $k \bar{a} s \underline{t}$ h $\bar{a}$ ) of reasoning (tarka, in TĀV IV 14, or sattarka, in TĀ IV 14), i.e., the 'ultimate term [or limit]' of certainty (niścaya, in v. 13) peculiar to 'those who know' (kovidāh, in IV 14), meaning that it consists in knowing that nonduality is the ultimate reality, as stated in PS 41 (advaitabhāvana), quoted supra.

Similarly, TĀV IV 13 (vol. 3: 629) teaches:

sa eva hi mahātmanām dehādyālocanena yathāyathamabhyāsātiśayāt vikalpaśuddhim ādadhānah, parām kāș̣̂hām upagatah san / bhāvanātmakatām yāyāt / yenāsphuțam api samvidrūpam sphuțatām āsādayet /,

\footnotetext{
132 GAS II 65: tapasvino vișayatyāga eva vișayagrahaṇe paryavasyati / dhyātvā hi te tyajyante / dhyānakāla eva ca sañgādaya upajāyante /, 'In the case of a tapasvin, the abandoning of an object of the senses culminates in the grasping of others, which are in turn abandoned by virtue of his meditation. Thus, at the very time of meditation, attachments, etc., arise.'

133 On a possible relative chronology of such texts, see Bansat-Boudon and Tripathi (2011, pp. 39-41).

134 On japa, see Bansat-Boudon and Tripathi (2011, pp. 261-265).

135 See supra, p. 49 and 52, n. 38, the usages of sphut and other related roots, such as sphar, sphur, etc. TĀV IV 13 makes also use of derivatives from the root sphut while commenting on the notion of bhāvanā.
} 
'Indeed, after [reasoning] has effected the purification of the thought constructs (vikalpaśuddhi) through one or another of the ways of reaching the end of the stage of repeated practice-[in other words] by studying the revered great Masters' [teachings] concerning the body, etc.-[that reasoning,] thereby reaching its ultimate limit, becomes bhāvana , by which [process] what was unclear (asphuta), even though of the form of consciousness, reaches clarity (sphutatā).'

This passage of TĀV sheds light on the textual organization of PS 39-41: 'The revered great Masters' [teachings] concerning the body, etc.' is an allusion to the eradication of the double error expounded in PS $39-40 ;{ }^{136}$ once the process of eradication is complete, in other words, once reasoning has reached its ultimate limit, annulled all idea of difference and become an inner certainty (niścaya, in TĀ IV 13), this certainty in turn becomes bhāvanā (the matter at issue in PS 41), the dazzling awareness of one's own essence as consciousness. In Yogarāja's commentary (PSV 39), the experience that transforms the yogin into a jivanmukta is expressed as: aham eva eko viśvātmanā sphurāmi, 'I alone manifest myself as the Self of the universe' - an inner discourse echoed in PSV 68 (supra, p. 87).

In the same line of thought, SpN II 6-7, quoting the SvT, defines bhāvanā as follows:

\section{[...] sarvam śivaśaktimayam smaret [v.l. (KSTS 44) sarvam śivamayam smaret] (SvT VII 244cd) //}

[...] jīvann eva vimukto 'sau yasyeyam [v.l. (KSTS 44) yasyaișā] bhāvanā sadā / yah śivam bhāvayen nityam na kālah kalayet tu tam [v.l. (KSTS 44) śivo hi bhāvito nityam na kālah kalayec chivam] (SvT VII 259) //,

" "One should consider everything as made of Śiva and Śakti". [...] He becomes liberated, even in this life, who gives himself over once and for all to that meditative realization (bhāvanāa), for time could not act on him who would realize (bhāvayet) Śiva continuously.'

Describing bhāvanā as the realization that everything is made of Śiva and Śakti (SvT VII 244cd, as quoted in the above passage from the $\mathrm{SpN}$ ), amounts to considering it as perfect knowledge (as stated by MVT XVII 20cd, quoted in TÂV IV 14), i.e., knowledge beyond words and the discursivity of reasoning:

tad eva paramạ̣ jũānam bhāvanāmayam ișyate,

'Supreme knowledge consists in bhāvanā. ${ }^{137}$

As such, the bhāvanā is characterized as instrumental in reaching the state of jīvanmukta or jūānin, 'he who knows [the Self]'. Specifically, it is an instrument of one of the 'ways' (upāya), the s'áktopāya. ${ }^{138}$ This is emphasized by the textual economy of the Paramārthasāra: immediately after the metaphorical description of bhāvan $\bar{a}$ as the winds fanning the blazing fire of the yogin's consciousness, v. 69

\footnotetext{
136 See supra, n. 100.

137 Compare with Śankara ad BhG II 66, quoted, supra, p. 91.

138 Also Silburn (1981, p. 191) and Chenet (1987).
} 
gives a vivid depiction of the jīvanmukta as living a carefree, utterly liberated existence:

\section{aśnan yadvā tadvā samvī̄to yena kenacic chāntah /}

yatra kvacana nivāsī vimucyate sarvabhūtātmā //,

'Eating whatever he finds, clad in whatever is available, tranquil, inhabiting anywhere at all, he is liberated who is the Self of all beings.'

As stated in PSV ad loc.:

yataḥ sa jūān̄i 'sarvabhūtātmā' sarveșām bhūtānām ātmā sarvāṇi ca bhūtāni tasyātmeti krtvā na kimcid bandhakatayā bhavati sarvam vimuktaye 'sya sampadyata iti,

'Because the knower of the Self knows himself as "the Self of all beings"the compound sarvabhütātman meaning [both] that he is the Self of all beings, and that all beings are his own Self-nothing exists for him as bondage; everything is conducive to his liberation.'

The śäktopāya thus culminates in bhāvanā, which in turn culminates in jīvanmukti, the main issue of the kārikās preceding and following PS 68, and particularly, kārikās $61^{139}$ and 69-73.

From all the sources presented here, it appears that the Saiva notion of bhāvanā has two faces: one which is "practical", inasmuch as, being a means in the śāktopāya, bhāvanā also pertains to yogic-or, more specifically, mantricpractice, as implied in PS $41 ;{ }^{140}$ and another which is "spiritual", and to which this "practical" function is subordinated; ${ }^{141}$ as such the Śaiva bhāvanā has two main characteristic features: i) the suddenness of spiritual revelation, emphasized by the recurrent use of the roots sphur / sphut and their derivatives, and ii) its uninterrupted nature. Once attained, spiritual revelation is attained once and for all ${ }^{142}$ and this justifies the metaphor of the japa or whispered recitation, in essence a continuous process, in VBh 145 quoted above, as well as that of the wind ceaselessly fanning the fire of consciousness, as in PS $68 .{ }^{143}$ As such, indeed, the Śaiva bhāvanā partakes of the esoterism of the doctrine.

\section{Bibliographic References}

\section{Abbreviations \\ EFEO École française d'Extrême-Orient. \\ GOS Gaekwad's Oriental Series. \\ HOS Harvard Oriental Series. \\ IFP Institut français de Pondichéry.}

\footnotetext{
${ }^{139}[\ldots]$ vigrahayoge 'py asau muktah, '[...] he is liberated though still joined with his body.'

140 See supra, p. 85.

141 As is the case with the practical function of the Mīmāmsaka bhāvanā; see supra, p. 83.

142 This is the famous statement, quoted in PSV 11: sakrd vibhāto 'yam ätmā; see supra, n. 31.

143 Note also the use of sadā in SvT VII 259b, of nityam in SvT VII 259c, supra, p. 93.
} 
IsMEO Istituto per lo studio del Medio ed Estremo Oriente.

JRAS Journal of the Royal Asiatic Society [of Great Britain and Ireland], Londres.

KSTS Kashmir Series of Texts and Studies.

Publ. EFEO Publications de l'EFEO.

Publ. ICI Publications de l'Institut de civilisation indienne (Collège de France).

SOR Serie orientale Roma.

SUNY State University of New York.

TSS Trivandrum Sanskrit Series.

\section{Editions}

[ĀPS = Ādiśeșa's Paramārthasāra $]$.

Gaṇapati Śāstri, T. (1911). The Paramârthasâra of Bhagavad Âdesesha, with the Commentary of Râghavânanda. Trivandrum: Government of His Highness the Maharajah of Travancore (TSS 12).

Danielson, H. (1980). Ādiśeșa, The Essence of Supreme Truth (Paramārthasāra). Sanskrit Text with Translation and Notes. Leiden: Brill (Nisaba: Religious Texts Translation Series 10).

[ĀS = Āgamaśāstra ] Bouy, Ch. (2000). Gauḍapāda, L'Āgamaśāstra. Un traité vedāntique en quatre chapitres. Texte, traduction et notes. Paris: De Boccard (Publ. ICI 69).

$[\mathrm{B} \overline{\mathrm{A}} \mathrm{U}=$ Br̆hadāranyakopanișad $]$ Radhakrishnan, S. (1978). The Principal Upaniṣads (with Śankarabhāsya) Edited with Introduction, Text, Translation and Notes. Delhi: Motilal Banarsidass $\left[1^{\mathrm{st}} \mathrm{ed}\right.$. London 1953.].

$[\mathrm{Bh}=$ Bhāskarī $]$ see ĪPK, Iyer, K.A. Subramanya, \& Pandey, K.C. (1986).

$[\mathrm{BhG}=$ Bhagavadgìtā $]$.

Edgerton, F. (1944). The Bhagavad-Gìtā. Translated and interpreted (2 Vols.). Cambridge, MA: Harvard University Press/London, H. Milford, Oxford University Press (HOS 38-39).

Gnoli, R. (1976). Il Canto del Beato (Bhagavadgītā). Turin: Unione tipografico-editrice torinese.

$[\mathrm{ChU}=$ Chāndogyopanișad $]$ see BĀU.

[ĪPK = İ́svarapratyabhijñākārikā $]$.

Iyer, K. A. Subramanya, \& Pandey, K. C. [Dwivedi, R.C. (Gen. Ed.)] (1986). Íśvara-PratyabhijñāVimarśini of Abhinavagupta: Doctrine of Divine Recognition. Vol. 1 and 2: Sanskrit Text with the Commentary Bhāskarī (Iyer, K. A. Subramanya, \& Pandey, K. C.); vol. 3: English Translation (Pandey, K. C.). Delhi: Motilal Banarsidass. [1st ed. Allahabad, Lucknow, 1930-1954 (The Princess of Wales Saraswati Bhavana Texts 70, 83, 84).].

Torella, R. (1994). The Íśvarapratyabhijñākārikā of Utpaladeva with the Author's Vṛtti. Critical Edition and Annotated Translation. Rome: IsMEO (SOR 71).

[ĪPV = İśvarapratyabhijñāvimarśinī] Kaul Shāstrī, M. (1921). The İśwarapratyabhijñā of Utpaladeva with the Vimarśinī by Abhinavagupta. Vol. 2. Srinagar: Research Department, Jammu \& Kashmir State (KSTS 33).

[ĪPVV = İśvarapratyabhijñāvivrtivimarśinī] Kaul Shāstrī, M. (1938-1943). Íśvarapratyabhijñā Vivrttivimarśini by Abhinavagupta. 3 vols. Srinagar: Research Department, Jammu \& Kashmir Government (KSTS 60, 62, 65).

[ĪPvr = İ́varapratyabhijñāvrtti $]$ see ĪPK Torella (1994).

[KU = Kathopaniṣad $]$ see BĀU.

$[\mathrm{MuU}=$ Muṇdakopaniṣad $]$ see BĀU.

[MVT = Mālinīvijayottaratantra] Kaul Shāstrī, M. (1922). Mālinivijayottaratantram. Srinagar: Research Department, Jammu \& Kashmir State (KSTS 37).

Mìmāmsānyāyaprakāśa. Edgerton, F. (1929). The Mīmāmsānyāyaprakāśa, or Āpadevī: A Treatise on the Mīmāmsā System by Āpadeva. Translated into English, with an Introduction, Transliterated Sanskrit Text and a Glossarial Index. New Haven, Conn.: Yale University Press.

[P. = Asțāadhyāyȳ] Chandra Vasu, S. (1962). The Aștāähyāyō of Pāninini. Edited and Translated into English (2 Vols.). Delhi: Motilal Banarsidass.

$[\mathrm{PH}=$ Pratyabhijñ̄āhrdaya $]$.

Chatterji, J. C. (1911). The Pratyabhijñā Hridaya of Kșhemarāja, Being a Summary of the Doctrines of the Advaita Shaiva Philosophy of Kashmir. Srinagar: Research Department, The Kashmir State (KSTS 3). 
Singh, J. (1987). Pratyabhijñāhrdayam. The Secret of Self-recognition. Sanskrit Text with English Translation, Notes and Introduction. Delhi: Motilal Banarsidass. [1st ed. 1963.].

$[\mathrm{PHvr}=$ Pratyabhijñāhrdayavrtti $]$ see $\mathrm{PH}$.

[PLM = Paramalaghumañjușā $]$ Shukla, K. (1961). Paramalaghumañjușā of Śri Nāgeśa Bhațta with the Commentary Jyotsnā by Pt. Kālikāprasād Shukla. Baroda: Baroda Sanskrit Mahavidyalaya (M.S. University of Baroda Research Series 7).

[PS = Paramārthasāra].

Bansat-Boudon, L., \& Tripathi, K. D. (2011). An Introduction to Tantric Philosophy: The Paramārthasāra of Abhinavagupta with the Commentary of Yogarāja [Translated by Lyne Bansat-Boudon and Kamaleshadatta Tripathi. Introduction, Notes, Critically Revised Sanskrit Text, Appendix, Indices by Lyne Bansat-Boudon]. London/New York: Routledge (Routledge Studies in Tantric Traditions 3).

Barnett, L. D. (1910). The Paramarthasara of Abhinavagupta, JRAS, 42: 707-747. [Reprint 2003: The Paramārthasāra of Ādi Śș̣a. Edited and Translated by Suryanarayana Sastri, S.S-The Paramarthasara of Abhinavagupta. Edited and Translated by Barnett, L.D. Fremont: Asian Humanities Press.].

Pandit, B. N. (1991). Essence of the Exact Reality, or Paramārthasāra of Abhinavagupta. Delhi: Munshiram Manoharlal.

Silburn, L. (1957). Le Paramārthasāra, texte sanskrit édité et traduit. Paris: De Boccard (Publ. ICI 5).

[PSV = Paramārthasāravivrti $]$ see PS.

$[$ SpK = Spandakārikā] Dyczkowski, M.S.G (1992). The Stanzas on Vibration. The Spandakārikā, with Four Commentaries: Spandasaṃdoha by Kșemarāja, Spandavrtti by Kallațabhațta, Spandavivriti by Rājanaka Rāma, Spandapradīpikā by Bhagavadutpala. Translated with Introduction and Exposition. Albany: SUNY Press (SUNY Series in Shaiva Traditions of Kasmir).

$[\mathrm{SpN}=$ Spandanirnaya $]$ Kaul Shāstrī, M. (1925). The Spandakarikas of Vasugupta, with the Nirnaya by Ksemaraja. Edited with Preface, Introduction and English Translation. Srinagar: Research Department, Jammu \& Kashmir State (KSTS 42).

[SpP = Spandapradīpikā] Śâstrî Islâmpurkar, V. (1898). The Spandapradīpikā of Utpalâchârya, a Commentary on the Spandakârikâ. Benares: Lazarus \& Co (Vizianagram Sanskrit Series 16 [vol. 14]), 1898.

[SvT = Svacchandatantra] Kaul Shāstrī, M. (1921-1935). The Swacchanda-Tantra with Commentary by Kshemarāja. 7 vols. Srinagar: Research Department, Jammu \& Kashmir State (KSTS 31, 38, 44, 48, $51,53,56)$.

$[\mathrm{SvTU}=$ Svacchandatantroddyota $]$ see SvT.

[ŚD = Śvivadrști $]$.

Kaul Shāstrī, M. (1934). The Sivadrișți of Srisomānandanātha, with the Vritti by Utpaladeva. Srinagar: Research Department, Jammu \& Kashmir Government (KSTS 54).

Nemec, J. (2011). The Ubiquitous Śiva: Somānanda's Śivadrșți and His Tantric Interlocutors. New York: Oxford University Press.

[ŚDvr = Śivadrsștivrtti $]$ see ŚD and Nemec (2011).

[ŚSV = Śivasūtravimarśinī $]$.

Chatterji, J. C. (1911). The Shiva Sütra Vimarshinī, Being the Sūtras of Vasu Gupta with the Commentary Called Vimarshin̄̄ by Kshemarāja. Srinagar: Archæological \& Research Department, Kashmir State (KSTS 1).

Singh, J. (1988). Śiva Sūtras: the Yoga of Supreme Identity. Text of the Sütras and the Commentary Vimarśinī of Kșemarāja. Translated into English with Introduction, Notes, Running Exposition, Glossary and Index. Delhi: Motilal Banarsidass. [1 ${ }^{\text {st }}$ ed. 1979.].

[ŚvU = Śvetāśvataropaniṣad $]$ see BĀU.

[T $\bar{A}=$ Tantrāloka $]$ Kaul Shāstrī, M. (1918-1938). The Tantrāloka of Abhinava Gupta with Commentary by Rājānaka Jayaratha. 12 vols. Srinagar: Research Department, Jammu \& Kashmir State (KSTS 23, $28,29,30,35,36,41,47,52,57,58,59)$.

$[\mathrm{TA} \mathrm{V}=$ Tantrālokaviveka $]$ see $\mathrm{TA}$.

[VBh = Vijñānabhairava $]$ Rāma Shāstrī, M. (1918). The Vijñāna-Bhairava with Commentary Partly by Kșhemarāja [v. 1-23] and Partly by Shivopādhyāya. Srinagar: Research Department, Jammu \& Kashmir State (KSTS 8). 


\section{Studies}

Bansat-Boudon, L. (1992). Poétique du théâtre indien. Lectures du Nātyaśāstra. Paris: École française d'Extrême-Orient (Publ. EFEO 169).

Bansat-Boudon, L. (2008). Introduction au śivaïsme non dualiste du Cachemire. Lectures du Paramārthasāra (2002-2007), Annuaire de l'École pratique des hautes études, Section des sciences religieuses. Résumé des conférences et travaux, t. 115 (2006-2007), 57-65.

Chenet, F. (1987). Bhāvanā et créativité de la conscience. Numen, 34(1), 45-96.

Coward, H. G., \& Kunjunni Raja, K. (2001). The Philosophy of the Grammarians. In K. Potter (Ed.). Encyclopadia of Indian Philosophies, vol. 5. Delhi: Motilal Banarsidass $\left[1^{\text {st }}\right.$ ed. Princeton University Press, 1990].

Goodall, D. (2012). pāśa-. In D. Goodall, \& M. Rastelli (Eds), Tāntrikābhidhānakośa: Dictionnaire des termes techniques de la littérature hindoue tantrique / A Dictionary of Technical Terms from Hindu Tantric Literature / Wörterbuch zur Terminologie hinduistischer Tantren. Vienna, Österreichischen Akademie der Wissenschaften, vol. 3.

Hulin, M. (1978). Le Principe de l'ego dans la pensée indienne classique. La notion d'ahaṃkāra. Paris: De Boccard (Publ. ICI 44).

Kane, P.V. (1962). History of Dharmaśāstra, vol. 5, part 2. Poona: Bhandarkar Oriental Research Institute (Government Oriental Series, Class B, 6).

Kiparsky, P. (1993). Pāṇinian Linguistics. In R. E. Ascher \& J. M. Y. Simpson (Eds.), Encyclopedia of Language and Linguistics (Vol. 6, pp. 2918-2923). Oxford, New York: Pergamon Press.

Mayrhofer, M. (1956-1980). KEWA = Kurzgefasstes etymologisches Wörterbuch des Altindischen. 4 vols. Heidelberg: Winter (Indogermanische Bibliothek).

Pokorny, J. (1959). Indogermanisches etymologisches Woerterbuch. Bern und München: Francke Verlag.

Ratié, I. (2011). Le Soi et l'Autre. Identité, différence et altérité dans la philosophie de la Pratyabhijñā. Boston-Leiden: Brill (Jerusalem Studies in Religion and Culture 13).

Renou, L. (1942). Terminologie grammaticale du sanskrit. Pt. 1 \& 2. Paris: É. Champion (Bibliothèque de l'École des hautes études, Sciences historiques et philologiques 280, 281).

Rix, H. (2001). Lexicon der indogermanischen Verben. Wiesbaden: Dr. Ludwig Reichert Verlag.

Sanderson, A. (1992). The Doctrine of the Mālinīvijayottaratantra. In T. Goudriaan (Ed.), Ritual and Speculation in Early Tantrism. Studies in Honor of André Padoux (pp. 281-312). Albany: SUNY Press (SUNY Series in Tantric Studies).

Sanderson, A. (1995). Meaning in Tantric Ritual. In A.-M. Blondeau, \& K. Schipper (Eds), Essais sur le rituel III. Colloque du centenaire de la section des sciences religieuses de l'École pratique des hautes études (pp. 15-95). Louvain-Paris: Peeters.

Sanderson, A. (2005). A Commentary on the Opening Verses of the Tantrasāra of Abhinavagupta. In S. Das, \& E. Fürlinger (Eds), Sāmarasya, Studies in Indian Arts, Philosophy and Interreligious Dialogue in Honour of Bettina Baümer (pp. 79-138). New Delhi: D.K. Printworld.

Sanderson, A. (2007). The Śaiva Exegesis of Kashmir. In D. Goodall, \& A. Padoux (Eds), Mélanges tantriques à la mémoire d'Hélène Brunner (pp. 231-442). Pondicherry: IFP-EFEO (Collection Indologie 106). 